
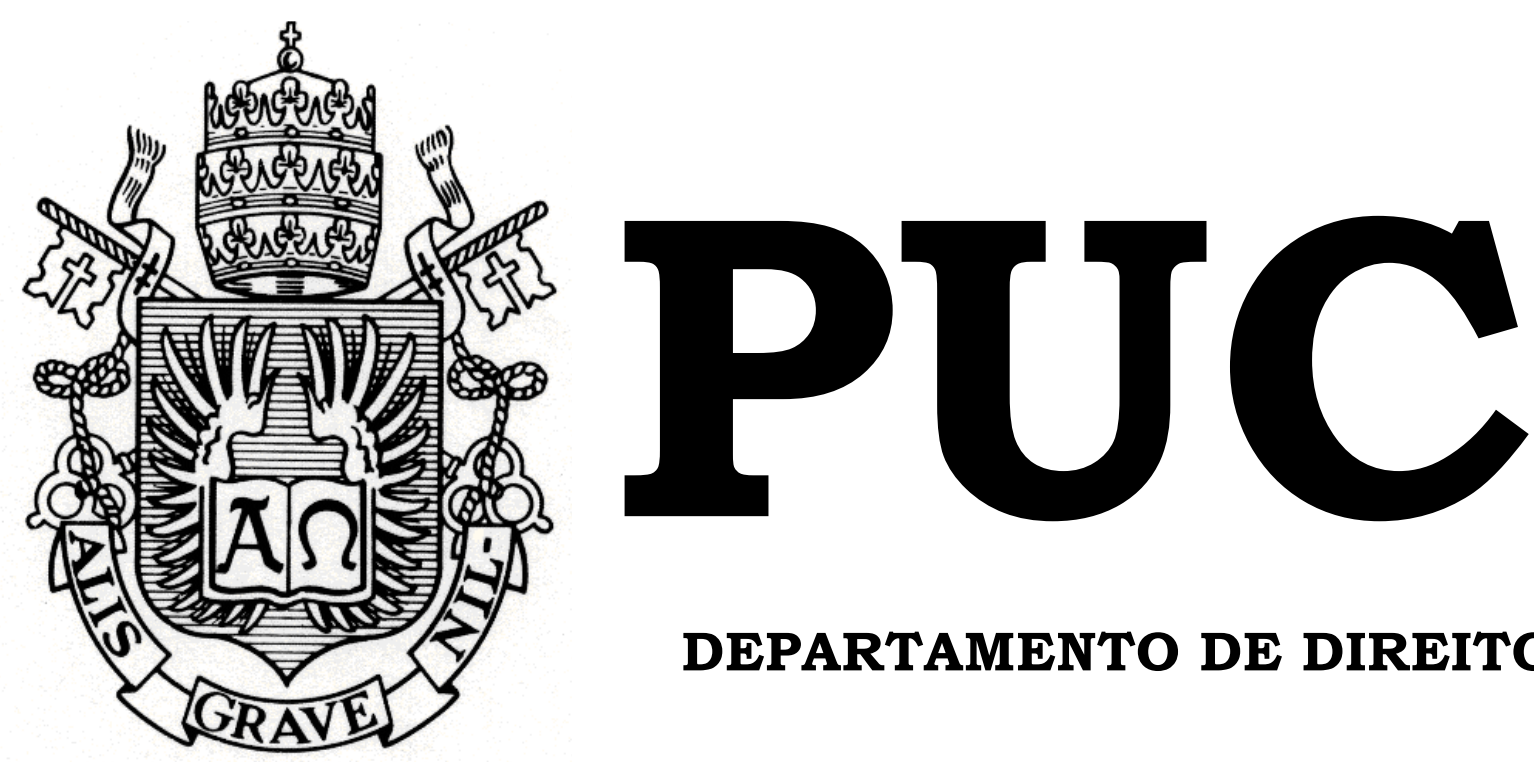

DEPARTAMENTO DE DIREITO

\title{
DIREITO E GÊNERO: UM ESTUDO COMPARADO DO PL 5002/13 E DA LEI DE IDENTIDADE DE GÊNERO ARGENTINA
}

\section{Por}

LUIZA FERRANTE MUANIS BECKER

ORIENTADOR: Adriana Vidal de Oliveira

\section{1}

PONTIFÍCIA UNIVERSIDADE CATÓLICA DO RIO DE JANEIRO

RUA MARQUÊS DE SÃO VICENTE, 225 - CEP 22451-900

RIO DE JANEIRO - BRASIL 


\title{
DIREITO E GÊNERO: UM ESTUDO COMPARADO DO PL 5002/13 E DA LEI DE IDENTIDADE DE GÊNERO ARGENTINA
}

\author{
por \\ LUIZA FERRANTE MUANIS BECKER \\ Monografia apresentada ao \\ Departamento de Direito da \\ Pontificia Universidade Católica do \\ Rio de Janeiro (PUC-Rio) para a \\ obtenção do Título de Bacharel em \\ Direito.
}

Orientadora: Adriana Vidal de Oliveira 


\section{AGRADECIMENTOS}

A todas, pela companhia nesse caminho de eterna (des)construção.

À Gab, por tudo que é para mim. 


\section{RESUMO}

BECKER, Luiza Ferrante Muanis. Direito e Gênero: Um Estudo Comparado do PL 5002/13 e da Lei de Identidade de Gênero Argentina. Rio de Janeiro: 2018: 78 p. Monografia de final de curso. Departamento de Direito da Pontifícia Universidade Católica do Rio de Janeiro - PUC-Rio.

O presente trabalho tem por objetivo a análise do Projeto de Lei $n$. 5002/2013, que atualmente tramita no Congresso Nacional, e da Lei de Identidade de Gênero Argentina, diploma legal no qual o projeto espelhouse. Esse estudo será amparado, também, pela análise dos movimentos sociais e teorias que contribuíram sobremaneira para a construção do conceito de "identidade de gênero", adotado pelo referido projeto de lei. Por fim, por meio da experiência comparada, objetiva-se demonstrar a precariedade do tratamento jurídico conferido aos indivíduos transgêneros pelo ordenamento jurídico brasileiro e a latente necessidade de conversão do PL n. 5002/2013 em lei.

Palavras-Chave: Teoria Queer. Transgênero. Direito à Identidade de Gênero. Lei de Identidade de Gênero Argentina. Projeto de Lei n. 5002/13. 


\section{SUMÁRIO}

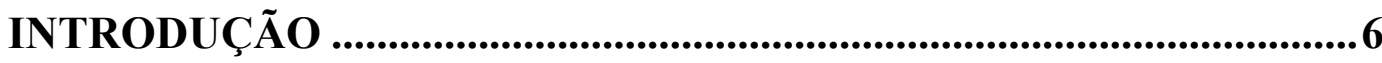

CAPÍTULO 1 - PANORAMA SOBRE A IDENTIDADE DE GÊNERO

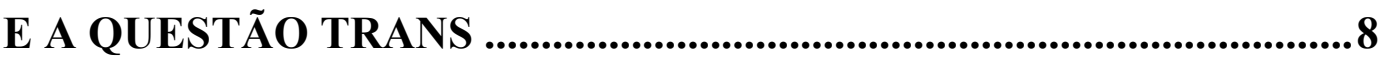

1.1 A Terceira Onda do Feminismo - O feminismo pós- estruturalista....8

1.2 As Teorias de Gênero ...................................................................11

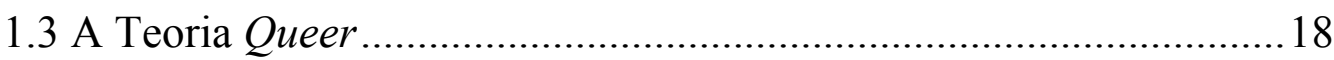

1.4 Aspectos da Transexualidade .........................................................20

CAPÍTULO 2 - A LEI DE IDENTIDADE DE GÊNERO ARGENTINA .22

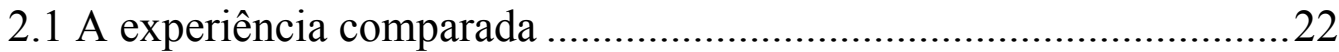

2.2 Lei n. 26.743/12: Ley de Indentidad de Género Argentina................23

2.2.1 Análise dos Principais Aspectos ................................................26

2.2.2 Comentários Conclusivos ........................................................30

CAPÍTULO 3 - O DIREITO BRASILEIRO E OS TRANSGÊNEROS

.33

3.1 Sobre as Cirurgias de Transgenitalização..............................................34

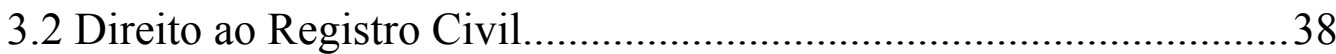

3.3 Ação Direta de Inconstitucionalidade n. 4275 .....................................41

3.4 Projeto de Lei n. 5002/2013. .........................................................4

3.4.1 Análise dos Principais Aspectos do PL n. 5002/2013 ................47

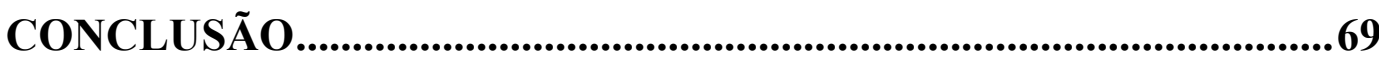

REFERÊNCIAS BIBLIOGRÁFICAS ........................................................71 


\section{LISTA DE ABREVIAÇÕES}

ABGLT - Associação Brasileira de Gays, Lésbicas, Bissexuais, Travestis e Transexuais

ADI - Ação Direta de Inconstitucionalidade

CID - Classificação Internacional de Doenças

CFM - Conselho Federal de Medicina

CRFB - Constituição da República Federativa do Brasil

FNLIG - Frente Nacional por la Ley de Identidad de Género

GLBTT - Gays, Lésbicas, Bissexuais, Travestis e Transexuais

LGBT - Lésbicas, Gays, Bissexuais, Transexuais

MPF - Ministério Público Federal

OMS - Organização Mundial de Saúde

ONU - Organização das Nações Unidas

PGR - Procuradoria Geral da República

PL - Projeto de Lei

PMO - Plan Médico Obligatorio

PSOL - Partido do Socialismo e Liberdade

PT - Partido dos Trabalhadores

RE - Recurso Extraordinário

RS - Rio Grande do Sul

STF - Supremo Tribunal Federal

SUS - Sistema Único de Saúde 


\section{INTRODUÇÃO}

O presente trabalho de monografia perpassa por questões de diversas ordens - políticas, históricas e sociais -, que, a princípio, podem ecoar como completamente avessas ao estudo das ciências jurídicas. Contudo, todas essas questões culminam em um elemento inerente a todo e qualquer indivíduo ou coletividade: os direitos humanos, especificamente, o direito à autodeterminação.

Do ponto de vista histórico e social, recebe especial destaque a análise do histórico do movimento feminista no mundo. Partindo-se da análise da primeira onda, trata-se sobre a evolução desse movimento - segunda onda e terceira onda/pós-feminismo-, que foi responsável por permear as primeiras discussões sobre sexo, sexualidade (orientação sexual) e gênero, que, eventualmente, levaram as primeiras teorias de gênero e à teoria queer.

Através da análise dos pensamentos de autoras pertencentes ao movimento do feminismo pós-estruturalista -terceira onda-, como Judith Butler e Joan Scott, que são objeto do primeiro capitulo, discorre-se sobre os principais aspectos da evolução e construção do conceito de identidade de gênero como característica dissociada da sexualidade, bem como sobre como essas teorias contribuíram para o rompimento de relações dicotômicas entre os sexos e para o entendimento do gênero como resultado de uma construção social, e não como proveniente de um determinismo natural.

Com essa análise introdutória, objetiva-se fomentar $\mathrm{o}$ estudo $\mathrm{e}$ compreensão da precariedade do ordenamento jurídico pátrio no que se refere ao tratamento jurídico concedido aos indivíduos transgêneros ${ }^{1}$, que, em razão da inércia do Poder Legislativo, validada e incentivada pelo sentimento de preconceito e rejeição demonstrados pela maior parte da sociedade, falha em

\footnotetext{
${ }^{1}$ Ao longo deste trabalho, serão utilizados os termos "transgênero" e "transexual" como sinônimos. Isto é, ambos os termos serão utilizados para definir aqueles indivíduos que possuem uma identidade de gênero diferente daquela designada no seu nascimento. Contudo, é necessário ressaltar que, na prática, esses conceitos não se confundem. $\mathrm{O}$ transexual, diferentemente do trangênero, que apenas deseja poder se expressar como sendo do sexo/gênero oposto (por meio das roupas, por exemplo), possui um forte desejo de modificar o seu corpo, o que pode ser feito através de cirurgia e/ou tratamento hormonal.
} 
garantir o pleno exercício por estes indivíduos do seu direito humano e fundamental de existir conforme sua autopercepção.

A partir do estudo da experiência comparada do exemplo da Argentina, país este que é mundialmente reconhecido por tratar de forma pioneira a questão dos transgêneros em absoluta consonância com os direitos humanos por meio da Lei n. 26.743/2012, a Ley de Identidad de Género, irá se discorrer sobre o tratamento conferido aos indivíduos transgêneros pelo Direto Brasileiro, no que se refere ao acesso à cirurgia transgenitalizadora e ao tratamento hormonal e, ainda, à retificação dos Registros Civis, tanto do ponto de vista da jurisprudência, quanto do ponto de vista legislativo.

Ao final, irá ser minuciosamente abordado o Projeto de Lei n. 5002/2013, também conhecido como a Lei João Nery, que é de autoria dos Deputados Federais Jean Wyllys (PSOL) e Érila Kokay (PT) e, vale dizer, espelhou-se quase de forma absoluta na Lei de Identidade de Gênero Argentina, demonstrando-se a latente necessidade de conversão deste em Lei Federal, para que, finalmente, o Poder Legislativo brasileiro saia da situação de inércia em que se encontra por demasiado tempo e que os indivíduos transgêneros sejam percebidos como sujeitos de direito. 


\section{CAPÍTULO 1 - PANORAMA SOBRE A IDENTIDADE DE GÊNERO E A QUESTÃO TRANS}

O presente capítulo possui o objetivo de discorrer sobre os principais aspectos da evolução e construção do conceito de identidade de gênero, analisando-se, para tanto, os pensamentos de autoras pertencentes ao movimento do feminismo pós-estruturalista, como Judith Butler e Joan Scott, e, ainda, a teoria queer, que, mais recentemente, vem mobilizando estudos neste campo.

A análise dessas teorias é imprescindível para a efetiva compreensão das diferenças entre a identidade de gênero de uma pessoa e a sua sexualidade (orientação sexual), conceitos estes que são reiteradamente confundidos, - sendo o primeiro, essencial à percepção do precário tratamento concedido pelo ordenamento jurídico brasileiro aos indivíduos transgêneros. Nesse mesmo sentido, o estudo desses temas se mostra essencial para a compreensão do movimento trans e da luta pelo direito à identidade de gênero, que, no Brasil, é em última instância representada pelo Projeto de Lei n. 5002/2013, que, atualmente, tramita na Câmara dos Deputados do Congresso Nacional.

\subsection{A Terceira Onda do Feminismo - O feminismo pós- estruturalista}

O feminismo é um movimento social que surgiu após a Revolução Francesa, inspirado pelos ideais iluministas. A primeira onda desse movimento foi bastante extensa, iniciando-se no século XIX e com fim nos primeiros anos do século XX, e ocorreu principalmente no Reino Unido e nos Estados Unidos. Foi durante esse período que o movimento feminista se consolidou como a luta pela igualdade de direitos entre as mulheres e os homens, o que se refletia em reivindicações diretamente relacionadas à derrubada de obstáculos legais à igualdade de gênero, ou seja, pela conquista dos direitos de propriedade, de 
igualdade de direitos nas relações contratuais e pelo direito ao voto ${ }^{2}$, bem como na oposição aos casamentos arranjados ${ }^{3}$.

A segunda onda desse movimento ocorreu durante as décadas de 60 e 80 do século $\mathrm{XX}$, que foram marcadas por revoluções como o movimento hippie, manifestações estudantis, manifestações contra a guerra e, na América Latina, contra os regimes ditatoriais. Durante esse período, principalmente na França e nos Estados Unidos, a principal bandeira era a luta contra a discriminação de gênero. Ademais, buscava-se alcançar o respeito às diferenças e a igualdade de direitos com base na igualdade entre os sexos, o que se refletia em palavras de ordem como "diferentes, mas não desiguais" e "a cor do batom é vermelha e a opressão também",4.

A terceira onda do movimento feminista se iniciou na década de 80 e perdura até os dias atuais, caracterizando-se por repensar e aprofundar questionamentos e reivindicações já levantados nas ondas anteriores. Apesar de a segunda onda ter sido relevante para inúmeras conquistas, este momento foi e ainda é responsável pelo aprimoramento destas através da luta pela mudança de estereótipos e da linguagem utilizada para definir as mulheres.

É imprescindível dizer que em cima dessa denominação - terceira onda revelasse um impasse teórico. Isso porque acredita-se ser "pós-feminismo" um termo mais adequado para definir esse período. Independentemente da nomenclatura escolhida, diante da notoriedade do fato de que esta fase deu voz à luta contra diversas outras opressões - raça, classe e orientação sexual - é incontroverso que foi nesse momento que as questões LGBT ganharam espaço ${ }^{5}$.

Durante essa fase:

\footnotetext{
${ }^{2}$ Em 06 de fevereiro de 1918, as mulheres com mais de 30 (trinta) anos conquistaram o direito ao voto no Reino Unido. A conquista desse direito ocorreu depois de um movimento social liderado pelas "sufragistas" que culminou na aprovação de alterações na lei eleitoral pelo Parlamento Britânico.

${ }^{3}$ LICÍNIO, José Vaughan Jennings Holanda. Uma crítica queer ao tratamento jurídico do casamento igualitário e da mudança de sexo no Brasil. Márcia Nina Bernardes (Orientadora). Rio de Janeiro, 2014. Monografia (Graduação em Direito) - Departamento de Direito, PUC-Rio, 2014. p. 38.

${ }^{4}$ Segunda onda feminista desigualdades culturais-discriminação e políticas das mulheres. Disponível em: <http://justificando.cartacapital.com.br/2017/09/14/segunda-onda-feminista-desigualdades-culturaisdiscriminacao-e-politicas-das-mulheres/-> . Acesso em: 11 mai. 2018.

${ }^{5}$ LICÍNIO, op. cit., p. 40.
} 
O objetivo passou a ser o reconhecimento de diversas identidades femininas e o abandono da ideologia do 'feminismo vítima', aplicada ao feminismo da segunda onda, em um interpretação pós-estruturalista do gênero e da sexualidade ${ }^{6}$.

A interpretação pós-estruturalista do gênero e da sexualidade são originárias de teorias caracterizadas por questionar o universalismo, $\mathrm{o}$ essencialismo, o binarismo e o racionalismo iluminista ${ }^{7}$, resultando naquilo que é conhecido como teorias de gênero.

Dentro do movimento pós-estruturalista existem ideias diferentes, teórica e metodologicamente ${ }^{8}$, sendo certo, contudo, que todos os pensamentos convergem na tentativa de se desconstruir a existência de um sujeito universal do feminismo, por meio da desconstrução da ideia de gênero como algo normatizador que implica na construção de algum tipo de unidade.

As teorias do feminismo pós-estruturalista aprofundaram questões suscitadas por autoras pertencentes à segunda onda do movimento, como Simone de Beavouir, conhecida por sua frase em O Segundo Sexo ${ }^{9}$ - "Não se nasce mulher, torna-se mulher" -, que impulsionou discussões sobre a diferenciação entre sexo e gênero, definindo o primeiro como uma consequência biológica -isto é, da anatomia do indivíduo- e o segundo uma construção cultural acerca do sexo feminino e masculino.

Apesar da manifesta importância dessa fase - segunda onda - e das questões levantadas pelas autoras que fazem parte desse período, as teorias pósestruturalistas possuem entendimento divergentes acerca dos conceitos de sexo e gênero, que, em síntese, baseia-se na tentativa de pôr fim ao universalismo do sujeito do feminismo e de abraçar todas as mulheres - negras, pobres e, até mesmo as transexuais -, e não somente aquelas que se enquadram em um conceito padronizado, unificado e opressor.

\footnotetext{
6 Disponível em: <http://justificando.cartacapital.com.br/2017/09/15/o-que-pede-terceira-ondafeminista/>. Acesso em: 12 mai. 2018.

${ }^{7}$ MARIANO, Silvana Aparecida. O sujeito do feminismo e o pós-estrutulismo In: Rev. Estud. Fem. v. 13, no. 3. Florianópolis: Sept./Dec. 2005, p. 3. Disponível em: <http://dx.doi.org/10.1590/S0104026X2005000300002>. Acesso em: 28 mar. 2018.

${ }^{8}$ Ibid., p. 1.

9 A Obra "O Segundo Sexo" foi publicada originalmente em 1949. Nesta obra, Simone de Beavouir faz uma análise sobre o papel da mulher na sociedade.
} 


\title{
1.2 As Teorias de Gênero
}

Nas palavras de Claudia de Lima Costa, as teorias de gênero, que serão analisadas ao longo deste capítulo, revelaram que:

\begin{abstract}
Embora as categorias modernas e valores do iluminismo - tais como direitos, igualdade, liberdade, democracia - inicialmente tenham instruído muitos dos movimentos feministas de emancipação, o discurso humanista da teoria moderna, juntamente com suas noções de Sujeito e Identidade intrinsicamente essencialistas, fundacionalistas e universalistas, tendeu a apagar as especificidades (de gênero, de classe, de raça, de etnia e de orientação sexual, etc.) dos diferentes sujeitos que ocupavam outras fronteiras políticas que aquelas do homem branco, heterossexual e detentor de propriedades ${ }^{10}$.
\end{abstract}

As teorias aqui expostas foram elaboradas por Judith Butler e Joan Scott, duas das principais teóricas do assunto. Embora as autoras apresentem ideias capazes de dialogar entre si - como a proposta de romper com as relações dicotômicas entre os sexos - é importante perceber que elas se valem de contextos diferentes para tanto, e por sua amplitude e relevância para o estudo das questões de gênero que seus pensamentos serão expostos neste trabalho.

O estudo de Scott será demonstrado a partir das noções construídas em seu artigo "Gênero: Uma Categoria Útil para Análise Histórica" ". No referido artigo, a autora estabelece que seu entendimento sobre gênero apresenta duas partes principais e alguns subconjuntos.

De início, fala-se de um núcleo embasado na conexão crucial das preposições: “(i) o gênero é um elemento constitutivo de relações sociais baseadas nas diferenças percebidas entre os sexos e (ii) o gênero é a forma primária de dar significado às relações de poder."

Isto posto, Scott enumera os aspectos do gênero enquanto um elemento constitutivo das relações sociais baseadas nas diferenças percebidas.

\footnotetext{
${ }^{10} \mathrm{COSTA}$, Claudia de Lima. O feminismo e o pós-modernismo/pós-estruturalismo: (in)determinações da identidade nas (entre)linhas do (con)texto In: PEDRO, Joana Maria; GROSSI, Miriam Pillar (Orgs.). Masculino, feminino, plural: gênero na interdisciplinariedade. Florianópolis: Editora Mulheres, 2000. p. 59 apud MARIANO. O Sujeito do Feminismo e o Pós-Estruturalismo In: Rev. Estud. Fem. v. 13, no. 3. Florianópolis: Sept./Dec. 2005. p. 4.

${ }^{11}$ SCOTT, Joan W. Gênero: uma categoria útil de análise histórica In: Educação e Realidade. Porto Alegre, v. 16, n. 2, 1990. p. 5-22.
} 
O primeiro, diz respeito a representações simbólicas da cultura que se revelam com frequência contraditórias, trabalhando os mitos de luz/escuridão, purificação/poluição, inocência/corrupção. $O$ segundo sugere que as interpretações dos significados dos símbolos produzem conceitos normativos que atuam no sentido de limitar e conter possibilidade metafóricas. Nas palavras de Joan:

Esses conceitos estão expressos nas doutrinas religiosas, educativas, científicas, políticas ou jurídicas e tomam a forma típica de uma oposição binária fixa, que afirma de maneira categórica e inequívoca o significado do homem e da mulher, do masculino e do feminino ${ }^{12}$.

Para a autora, a problemática repousa na noção de fixidez que a história assegura a essas noções. Isso porque são postas como noções nascidas de um consenso, e não do conflito, o que leva a naturalização das ideias, como se aquelas marcas fossem as únicas possíveis. Por esse motivo, seria necessário o esforço de nova pesquisa histórica no sentido de combater essa rigidez de uma representação binária de gênero.

Nesse sentido que se desenvolve o terceiro aspecto entendido pela pensadora pós-estruturalista, qual seja, a repressão dessa estrutura arraigada e o questionamento dessa estrutura binária posta como natural. Segundo Scott, O intuito é de descobrir a origem do debate que naturaliza os papéis impostos aos gêneros em um víes binário, como se fossem incontestáveis.

Com efeito, o que se percebe é que, para a investigação da origem dessas concepções supostamente "tradicionais", deve-se levar em conta a análise de uma concepção política, assim como a organização social e instituições.

O quarto e último aspecto percebido pela teórica diz que o gênero é uma identidade subjetiva. Neste ponto, Scott problematiza a concepção universal da psicanálise de que o gênero nasce de uma vivência cultural da sexualidade

\footnotetext{
${ }^{12}$ SCOTT, 1990, p. 16.
} 
biológica, o que significa dizer que o gênero nada mais é do que o atributo correlacionado ao sexo no âmbito da cultura ${ }^{13}$.

Embora a autora acredite que esta reflexão possa ser útil para entender as identidades generificadas, entende que não se faz possível conduzir a pesquisa sem levar em conta aspectos de ordem histórica. Justifica-se tal necessidade pelo simples fato de estar-se diante de uma sociedade onde homens e mulheres não cumprem integralmente e, muito menos, em todas as ocasiões as prescrições inscritas sobre as categorias analíticas. Por essa razão, conclui que é preciso procurar pelas origens dessas construções de identidade subjetivamente atribuídas binariamente aos corpos e sempre correlacioná-las aos aspectos organizacionais, políticos e sociais para melhor compreendê-las.

Esta primeira definição compila quatro aspectos que esboçam ideias sobre a construção de gênero, sobre a influência dos fatores políticos, culturais, institucionais e sociais nesse trabalho. Ademais, convida a reflexão acerca das origens históricas, dos aspectos conflitantes e da problematização das estruturas de poder $^{14}$.

Já a sua segunda premissa afirma que "o gênero é uma forma primária de dar significado às relações de poder". Essa preposição nasceria da percepção do gênero como um elemento em que constantemente são legitimadas formas de articulação de poder. Contudo, entende que, para que tais atribuições sejam possíveis, seria necessário um processo de naturalização das marcas biológicas, afirmando uma diferenciação entre os sexos. Essa diferenciação deveria ser forte o suficiente para testemunhar vivências sociais que nada dizem respeito a esse aspecto, corroborando com essa legitimação. Como pode ser visto:

O sociólogo francês Pierre Bourdieu tem escrito sobre como a "di-visão do mundo", baseada em referências às "diferenças biológicas, e, notadamente, àquelas que se referem à divisão do trabalho de procriação e de reprodução", operam como "a mais fundada das ilusões coletivas". Estabelecidos como um conjunto objetivo de referências,

\footnotetext{
${ }^{13}$ SCOTT, 1990, p. 17.

${ }^{14}$ Ibid., p. 18.
} 
os conceitos de gênero estruturam a percepção e a organização concreta e simbólica de toda a vida social ${ }^{15}$.

Com essas ideias, Scott fala sobre outros pensadores que analisaram a legitimação do gênero através de diversas culturas ${ }^{16}$, trazendo à tona a diferença sexual como um forma primária de significar essa diferenciação, e o gênero como fator de decodificação desses significado e auxiliador no processo de compreensão das interações humanas.

Como pensadora pós-estruturalista, Scott lê o gênero como um aspecto flutuante ao longo da história, que está à disposição das necessidades do Estado, capaz de atender a demanda cultural que se mostra necessária em determinado momento. A título de exemplo:

Crises demográficas, causadas pela fome, pestes ou guerras, podem ter colocado em questão visões nonnativas de casamento heterossexual (como foi o caso em certos meios e certos países no correr dos anos 1920); mas elas igualmente provocaram políticas pró-natalistas que insistiam na importância exclusiva das funções maternais e reprodutoras das mulheres ${ }^{17}$.

Sendo assim, pensando em gênero como algo não fixo, capaz de ser moldado e lapidado pelo Estado e pela sociedade e suas urgências e demandas, que a teórica entende este conceito como resultado de processos políticos movimentados por atores diferentes e significados diferentes, onde sempre prevalecerá um significado e assim será assegurado o controle.

Em consonância a onda feminista da qual faz parte, buscando quebrar o que havia sido entendido como uma "identidade feminina" e suas substanciais

\footnotetext{
${ }^{15}$ SCOTT, 1990, p. 19.

${ }^{16} \mathrm{~A}$ função de legitimação do gênero age de várias maneiras. Bourdieu, por exemplo, mostrou como, em certas culturas, a exploração agrícola era organizada segundo conceitos de tempo e de estação que se baseavam em definições específicas da oposição entre masculino e feminino. Gayatri Spivak fez uma análise perspicaz dos usos do gênero e do colonialismo em certos textos de escritoras britânicas e americanas. Natalie Davis mostrou como os conceitos de masculino e feminino estavam relacionados à aceitação e ao questionamento das regras da ordem social no primeiro período da França moderna. A historiadora Caroline Bynum deu nova luz à espiritualidade medieval pela importância atribuída às relações entre os conceitos do masculino e do feminino e o comportamento religioso. Seu trabalho nos permite melhor compreender as formas pelas quais esses conceitos orientaram a política das instituições monásticas e as crenças individuais. Os/as historiadores/as da arte abriram um novo território ao extrair implicações sociais das representações literais dos homens e das mulheres.

Ibid., p. 19.

${ }^{17}$ Ibid., p. 22.
} 
características, elemento que de certa forma, ainda fazia parte da agenda feminista que antecedeu o pós-estruturalismo, Scott fala da necessidade de não ser mais sustentado esse discurso de identidade que encarcera homens e mulheres em seus respectivos limites.

Para Scott, a compreensão de gênero envolve o reconhecimento do homem e da mulher como:

Ao mesmo tempo, categorias vazias e transbordantes. Vazias, porque não têm nenhum significado último, transcendente. Transbordantes, porque mesmo quanto parecem estar fixadas, ainda contêm dentro delas definições alternativas, negadas ou suprimidas ${ }^{18}$.

A crítica da teórica condena as relações assimétricas pautadas nas diferenças socialmente construídas entre homens e mulheres, rejeita o caráter fixo e permanente da oposição binária, assim como também o estudo de gênero na esfera doméstica e somente em relação a mulher. Com isso, o que se pretende é ampliar a compreensão dos papéis de gênero dentro de uma ordem social e a forma como se legitimam e se perpetuam, de modo a transformá-la ${ }^{19}$.

Enquanto isso, Judith Butler, em sua obra "Problemas de Gênero" 20, além de abordar a questão do gênero, mergulha, também, nos questionamentos aos aspectos binário e pré-discursivo do sexo. Para esta autora, o sexo, assim como o gênero, deriva de uma produção cultural posta pela sociedade, motivo pelo qual a sua concepção deve ser igualmente posta em xeque.

De início, ela fala sobre seu entendimento acerca possibilidade da distinção inaugurada pelo uso dos conceitos de sexo e gênero abrir questionamentos a respeito da unidade do sujeito. Ainda que a primeira seja proposta como um fato biológico, aparentemente intratável, a segunda se define por aspectos culturais atribuídos aos corpos, apresentando características de

\footnotetext{
${ }^{18}$ SCOTT, 1990, p. 23.

19 Disponível em: <http://www2.dbd.puc-rio.br/pergamum/tesesabertas/1211273_2014_cap_2.pdf>. Acesso em: 11 mai. 2018.

${ }^{20}$ BUTLER, Judith. Problemas de Gênero: Feminismo e subversão da identidade. Rio de Janeiro: Editora Civilização Brasileira, 2013. p. 7.
} 
maior fluidez. Assim, entende-se que o gênero pode ser uma múltipla interpretação do sexo.

O ponto levantado aqui elucida que a reprodução mimética de "homens" a corpos masculinos, e "mulheres" a corpos femininos não se faz razoável. Seria controverso supor que o gênero como significado cultural assumido pelo corpo sexuado decorra sempre do sexo, para tal propõe-se uma descontinuidade entre os dois conceitos - sexo e gênero ${ }^{21}$.

Outro questionamento de Butler, a partir da sugestão de corpos sexuados e gêneros culturalmente construídos está na problematização acerca do binarismo, tanto de sexo como de gênero. Essa ruptura corrobora com a quebra da estrutura mimética já questionada por Butler, uma vez que o gênero se afirma de fato como um artifício flutuante, permitindo que homem e masculino se combinem tanto com corpos femininos, como masculinos e vice-versa ${ }^{22}$.

Em relação ao conceito de sexo, trava-se um desejo de romper com os atributos naturais impostos a este cientificamente, o sexo dito como natural, anatômico, cromossômico, pré-discursivo e neutro não é recepcionado inquestionavelmente por Butler.

A autora busca uma genealogia capaz de explicar se esse fato imposto como ostensivamente natural um dia já foi recepcionado junto à hipóteses não binárias e se o discurso que hoje é conhecido deriva de interesses políticos e sociais. E, por fim, se todas essas possibilidades de questionamento não significassem que o sexo na realidade é uma construção cultural - assim como o gênero - e não restaria qualquer distinção entre os dois conceitos.

Em negativa a ideia de que o gênero não deve ser concebido como uma inscrição cultural de um sexo previamente dado $^{23}$, a autora enxerga que a

\footnotetext{
${ }^{21}$ BUTLER, 2013, p. 24-25.

${ }^{22}$ Ibid., p. 24-25.

${ }^{23}$ A leitura de Butler rompe com os pensamentos da segunda onda feminista, que ainda via a mulher como um sujeito marcado como o "Outro" por marcas biológicas e naturais que a aprisionavam a esta categoria, o questionamento do conceito de sexo inaugura um debate fundamental para o pósestuturalismo "Resulta daí que o gênero não está para cultura como o sexo para natureza; ele também é o meio discursivo/cultural pelo qual a 'natureza sexuada' ou o 'sexo natural'”. Ibid., p. 25.
} 
construção dual do sexo como algo pré-discursivo, supostamente neutro e natural, anterior à cultura, vulnerável as influências da mesma, como uma tela branca pronta para ser pintada, que teria colaborado para assegurar a estabilidade interna da estrutura binária.

Diante da percepção de uma possível indistinção entre sexo e gênero, que sugere que o sexo é nada mais do que uma produção discursiva do poder - que a este conceito atribuiu a qualidade de pré-discursivo - a autora desbrava novamente concepções ostensivamente naturais e problematiza a ordem genealógica dos conceitos.

Neste ponto, Judith Butler também apresenta indagações a respeito da possível solidez dos conceitos gênero e desejo ${ }^{24}$ - até então arraigados em uma perspectiva binária - dentro de uma matriz não-heterossexual. Questiona-se como se passaria a entender o sujeito e o gênero uma vez que desmascarado o regime epistemológico de presunção de heterossexualidade, em sua posição de produtor e reificador dessas categorias que se afirmam como ontológicas.

É nesse viés de problematização das categorias binárias de sexo e gênero e da heterossexualidade compulsória, bem como de combate a um sistema epistemológico/ontológico, que Butler permeia sua teoria de ressiginificação de gênero $^{25}$.

O desejo de expor a teorização das autoras a respeito do gênero - e outros conceitos em comento - teve como intuito, não só demonstrar as similitudes de alguns pontos, quais sejam: o questionamento do binarismo, da conexão compulsória de sexo-gênero, dos papéis impostos aos gêneros como se fossem incontestáveis e suas demais interseções, mas, também, para demonstrar que dentro do universo das teorias de gênero existem caminhos distintos para essa construção - embora, neste caso, o pensamento das autoras seja próximo.

Apesar da importância de ambas as autoras para o rompimento das relações dicotômicas entre os sexos, para o entendimento do gênero como algo

\footnotetext{
${ }^{24}$ Ao que se traduz, orientação sexual.

${ }^{25}$ BUTLER, 2013, p. 8.
} 
construído socialmente, não natural e alvo de influências de tempo e cultura, para fins de compreensão da importância da identidade de gênero para a questão trans, o presente trabalho será guiado principalmente através das concepções trazidas por Judith Butler, que, além de ocupar relevante papel no movimento feminista pós-estruturalista, também foi um das precursoras da teoria queer, tema a ser analisado no tópico a seguir.

\subsection{A Teoria Queer}

Como visto nos tópicos acima, o movimento feminista pós-estruturalista propunha a ideia de abraçar uma demanda cada vez mais ampla na luta pelos direitos das mulheres, cenário no qual surge a teoria queer. O termo "queer", originário da língua inglesa, significa estranho, esquisito, fora do padrão, isto é tudo aquilo que não está de acordo com o que se considera como esperado. Um contraponto à palavra "straight", que significa correto, reto e, ainda, heterossexual ${ }^{26}$.

Judith Butler, cujos pensamentos foram analisados anteriormente neste trabalho, foi uma das percursoras da teoria queer. Em sua obra "Problemas de Gênero" ${ }^{27}$, ao sugerir a existência de uma possível descontinuidade na relação entre sexo, gênero e desejo, embasando-se no argumento de que a suposta conexão entre esses três aspectos seria o resultado de uma concepção produzida dentro de uma matriz heterossexual, na qual convivem machos com aspectos masculinos e fêmeas com aspectos femininos, ambos movidos por desejos heterossexuais.

Ao supor que corpos não necessariamente obedecem a esta continuidade, a teoria queer abraça todos aqueles que não se enquadram em uma estrutura binária do sexo e/ou gênero, aqueles cujo sexo que lhes é designado não corresponde ao gênero com o qual se identificam e, ainda, aqueles cujo desejo não é heterossexual. Em outras palavras, os gays, as lésbicas, os hermafroditas,

\footnotetext{
${ }^{26}$ LICÍNIO, 2014, p. 50.

${ }^{27}$ BUTLER, 2013, p. 8.
} 
os transexuais, os transgêneros, as drags queens e todo um rol que não tem a pretensão de se esgotar, formado por indivíduos que não reproduzem essa conexão entre sexo, gênero e desejo, tida como obrigatória em uma sociedade heteronormativa.

Nas palavras de José Licínio, no âmbito dessa teoria:

A grande marca é uma desconfiança fundamental no que toca às pretensões universalistas de explicação da sexualidade e da identidade humana com base nos binarismos característicos da modernidade, o que demonstra uma afinidade teórica do queer com a pós-modernidade e sua crítica às grandes narrativas da modernidade ${ }^{28}$.

Ademais, por meio da teoria queer, é levantada a possibilidade de se entender a transexualidade através do fato de que a genitália do indivíduo não é fator determinante para a sua alternativa de identificação de gênero. E com isso, se estimula o respeito à ideia de que o gênero com o qual a pessoa se identifica não corresponde a um transtorno mental ou uma patologia e sim a uma mera subjetividade ao exercer seu direito à autodeterminação ${ }^{29}$.

No mais, cabe aqui, fazer uma sucinta distinção, fundamental para o desenvolvimento deste trabalho a respeito dos conceitos de identidade de gênero e orientação sexual - desejo.

O primeiro é um dado particular de cada pessoa, sendo a forma como um sujeito se identifica, autodetermina-se e como ele performa socialmente. Com a teoria queer, foi possível atribuir ao gênero um caráter subversivo, quebrando a compulsão binária - masculino e feminino - contemplando uma rica diversidade de identificações de gênero como, por exemplo, a androginia ou o não reconhecimento de nenhum desses gêneros ${ }^{30}$.

A orientação sexual ${ }^{31}$, ao que se entende, traduz a forma como o desejo do sujeito se materializa, sendo certo que não necessariamente a orientação sexual

\footnotetext{
${ }^{28}$ LICÍNIO, 2014, p. 53.

${ }^{29}$ SILVA, Bruna Camilo de Souza Lima e. Lei de Identidade de Gênero: Uma Análise Comparativa da Lei Argentina e o PL 5002/2013 do Brasil In: Libertas. Ouro Preto. ISSN 2319-0159 v. 2, nº 1, jan/ jun., 2016. p. 6.

${ }^{30}$ SILVA, 2016, p. 7.

${ }^{31}$ SILVA, Christiane Gonçalves da. Orientação sexual, identidades sexuais e identidade de gênero. Disponível em: <http://www.comfor.unifesp.br/wp-
} 
goza de fixidez e muito menos de racionalidade. Para entender esse conceito, a pergunta seria "Qual o sexo ou gênero que constitui seu objeto de desejo?

\subsection{Aspectos da Transexualidade}

Após a análise dos aspectos históricos e teóricos das questões relacionadas à identidade de gênero e à sexualidade e antes de se adentrar o universo jurídico, para a efetiva compreensão da dimensão e importância do reconhecimento do direito à identidade de gênero, faz-se necessário discorrer, ainda que brevemente, sobre alguns aspectos da transexualidade e o tratamento conferido aos indivíduos transgêneros sob o ponto de vista social e da medicina.

A "transexualidade é uma experiência identitária, caracterizada pelo conflito com as normas de gênero" ${ }^{\text {"32 }}$. Essa violação às normas de gênero ocorre de forma frontal e, reflete em uma forte estigmatização, margilinização e perseguição desses indivíduos. Segundo o entendimento de Jaqueline de Jesus, isto se dá:

Devido à crença na sua anormalidade, decorrente da crença de que o "natural" é que o gênero atribuído ao nascimento seja aquele com o qual as pessoas se identificam e, portanto, espera-se que elas se comportem de acordo com que se julga ser o "adequado: para esse ou aquele gênero ${ }^{33}$.

A aversão aos transgêneros se caracterizada pelo sentimento de transfobia, que, em alguma instância, respalda-se no atrasado posicionamento da Organização Mundial de Saúde, que, ainda hoje, inclui o transexualismo no rol de doenças mentais da Classificação Internacional de Doenças - CID. A última publicação (CID-10) data o ano de $2003 \mathrm{e}$, em seu capítulo V, enumera dentre os transtornos mentais e comportamentais os "transtornos de identidade sexual", o que inclui o "transexualismo".

Na forma da CID-10, F64.0, o "transexualismo" se enquadra como:

content/docs/COMFOR/biblioteca_virtual/GDE/mod3/Semana3_Mod3_GDE.pdf $>$. Acesso em: 02 jun. 2018 .

${ }^{32}$ BENTO, Berenice. O que é transexualidade. São Paulo: Brasiliense, 2008. p. 18.

${ }^{33}$ JESUS, Jaqueline Gomes de. Orientações sobre a população transgênero: conceitos e termos. Brasília: Autor, 2012. p. 11. 
Um desejo de viver e ser aceito enquanto pessoa do sexo oposto. Este desejo se acompanha em geral de um sentimento de mal estar ou de inadaptação por referência a seu próprio sexo anatômico e do desejo de submeter-se a uma intervenção cirúrgica ou a um tratamento hormonol a fim de tomar seu corpo tão conforme quanto possível ao sexo desejado ${ }^{34}$.

No Brasil, o Conselho Federal de Medicina regula a matéria da mesma forma. A Resolução 1.955/2010, a norma ética mais recente sobre o assunto, enquadra essa "condição" como patológica, determinando que "o paciente transexual portador de desvio psicológico permanente de identidade sexual, com rejeição do fenótipo e tendência à automutilação e/ou extermínio".

A nova Classificação Internacional de Doenças - a CID-11 - está sendo preparada e deverá ser submetida à Assembleia Mundial de Saúde no ano de 2018. Segundo vem sendo noticiado nos mais variados meios de comunicação, a CID-11 deve confirmar a tendência do processo de despatologização do "transexualismo", que deve ser deslocado do rol de doenças mentais, passando a ser definido como "incongruência de gênero",35.

Através da análise da evolução e da construção do conceito de gênero por autoras pertencentes ao movimento feminista pós-estruturalista e à teoria queer e, ainda, através da compreensão de certos aspectos relacionados à transexualidade, como, por exemplo, a manutenção até os dias atuais da sua patologização pela OMS e pelo Conselho Federal de Medicina do Brasil, buscou-se construir um panorama geral introdutório sobre a questão trans, para que, nos demais capítulos deste trabalho, seja possível aventar sobre o tratamento concedido aos indivíduos transgêneros na Argentina e no Brasil no que se refere ao direito à identidade de gênero.

\footnotetext{
${ }^{34}$ Disponível em: <http://www.datasus.gov.br/cid10/V2008/cid10.htm>. Acesso em: 19 mai. 2018.

${ }^{35}$ Notícias sobre a publicação da CDI-11 e sobre a retirada do "transexualismo" do rol de doenças mentais. Disponível em: <https://www.revistaencontro.com.br/canal/atualidades/2018/01/oms-reconhecea-obsessao-por-games.html>. Acesso em: 12 mai. 2018.

Ibid., Disponível em: <http://agenciabrasil.ebc.com.br/geral/noticia/2018-01/atualizacao-da-classificacaode-doencas-tera-transtornos-por-jogos-eletronicos>. Acesso em: 12 mai. 2018.
} 


\section{CAPÍTULO 2 - A LEI DE IDENTIDADE DE GÊNERO ARGENTINA}

\subsection{A experiência comparada}

Em razão da existência de um passado colonizador comum e da recente construção desses Estados Democráticos de Direito após longos anos de regimes ditatoriais, o Brasil e a Argentina possuem certa similaridade histórica. Devido a esta similaridade, na hipótese de constatação de avanços de ordem política, econômica e/ou social em qualquer um desses países, mostra-se absolutamente enriquecedor ao outro o estudo e a compreensão dos elementos que encadearam essas conquistas, sendo possível a reprodução interna dos seus efeitos. Nesse exato sentido, dispõe Heinzelamann:

[...] as peculiaridades do desenvolvimento de alguns países podem servir de base para se pensar sobre fenômenos similares que ocorrem em outras localidades e, assim, analisar as situações possíveis ou já efetivas de multiplicação interna ou regional de seus efeitos em termos de avanços em direitos humanos, quando satisfatórios ${ }^{36}$.

Por esse motivo, após a análise das teorias de gênero e da teoria queer, bem como da contribuição destas para a construção do conceito de identidade de gênero, objetiva-se, ao longo deste segundo capítulo, discorrer acerca da experiência argentina, internacionalmente reconhecida por seu pioneirismo e consonância com os direitos humanos, no que se refere à efetivação do direito à identidade de gênero através da Lei n. 26.743/12, a Ley de Identidad de Género ${ }^{37}$.

\footnotetext{
${ }^{36}$ HEINZELAMANN, Fernanda Lyrio. Lei de Identidade de Gênero: Podem experiências sulamericanas colaborar com o Brasil? In: 13th Women's Worlds Congress \& Fazendo Gênero 11 e. ISSN 2179 -501X. Anais... Florianópolis, 2017, Disponível em:

<http://www.en.wwc2017.eventos.dype.com.br/resources/anais/1498585756_ARQUIVO_HEINZ ELMANN_FRACCAROLI_FG_2017_Lei_de_identidade_de_genero.pdf> Acesso em: 23 mai. 2018.

${ }^{37}$ ARGENTINA. Ley n. 26.743 de mayo de 2012. Disponível em:

$<$ http://servicios.infoleg.gob.ar/infolegInternet/anexos/195000-199999/197860/norma.htm>

Acesso em: 13 mai. 2018.
} 
O estudo prévio do exemplo argentino é de suma importância para a efetiva compreensão da precariedade apresentada pelo ordenamento jurídico brasileiro no que se refere aos direitos humanos e, especificamente, à questão do direito à identidade de gênero - recentemente remediada pelo ativismo judicial do Supremo Tribunal Federal através do julgamento da ADI 4275 -, o que, de forma urgente, necessita ser reparado através da aprovação do Projeto de Lei n. 5002/2013, cuja redação espelha-se no exemplo argentino.

\subsection{Lei n. 26.743/12: Ley de Indentidad de Género Argentina}

A Ley de Identidad de Género da Argentina foi promulgada em 2012, tendo sido a sua elaboração e a sua aprovação resultantes da discussão sobre questões relacionadas à diversidade de gênero. A discussão desse tema nos países sul-americanos foi impulsionada pelo Uruguai, responsável por promulgar a Lei n. $18.620 / 2009^{3839}$, por meio da qual se permitiu a alteração do registro civil dos indivíduos transgêneros que tenham, ou não, realizado a cirurgia transgenitalizadora.

Posteriormente, conforme é sustentado por Heinzelamann ${ }^{40}$, essa discussão teria sido acelerada pela promulgação na própria Argentina da Lei de n. 26.618/2010 ${ }^{41}$ - Lei do Casamento Igualitário -, que representou uma revolução nos costumes e demonstrou a existência de uma sociedade

\footnotetext{
${ }^{38}$ SILVA, 2016, p. 8.

${ }^{39}$ No que se refere à lei uruguaia, cabe ressaltar que, apesar de esta ser anterior à lei argentina e de ter incentivado a discussão acerca da diversidade de gênero neste país, no que se refere aos elementos por ela abrangidos, verifica-se grande atraso desta em relação à Ley de Identidad de Género argentina. Isso porque, apesar de esse diploma legal dispensar a esterilização forçada (isto é, qualquer procedimento médico de mudança de sexo que afete os órgãos reprodutores) para fins de reconhecimento do gênero com o qual a pessoa se identifica, quando o indivíduo não tiver passado pela cirurgia transgenitalizadora (art. $3^{\circ}$ da Lei 18.620), ainda exige-se a presença de laudo médico e psicológico de acompanhamento, assim como o depoimento de pessoas próximas e provas de que aquele indivíduo vive há pelo menos dois anos sob as condições de gênero com a qual se identifica.

${ }^{40}$ HEINZELAMANN, 2017, p. 9.

${ }^{41}$ ARGENTINA. Ley n. 26.618, de 15 de julho de 2010. Promulgada em 21 de julho de 2010. Código Civil. Modificación. Boletín Oficial de la República Argentina, Buenos Aires, 21 jul. 2010. Disponível em: <http://servicios.infoleg.gob.ar/infolegInternet/anexos/165000169999/169608/norma.htm>. Acesso em: 15 mai. 2018.
} 
mais tolerante, conferindo aos seus cidadãos a possibilidade de exercer de forma plena esses direitos. Isso porque, com a aprovação desta lei, passouse a permitir o casamento entre pessoas do mesmo sexo, possibilitando-se, inclusive, a adoção de crianças por esses casais.

Posteriormente, como consequência de grande ativismo por parte dos movimentos sociais, foi idealizada em 2011 a construção da escola pública Mocha Celis ${ }^{42}$, instituição sem fins lucrativos e com apoio governamental, absolutamente voltada para a inclusão e acesso à educação dos indivíduos transgêneros, em um ambiente livre de descriminação. Esse sistema foi criado para reinserir no sistema educacional aqueles indivíduos expulsos de seus lares em idade impúbere, garantindo o afastamento de meios alternativos para seu sustento, como, por exemplo, a prostituição.

Em meio a esse cenário e com o fomento da militância da Frente Nacional por la Ley de Identidad de Género (FNLIG) ${ }^{43}$, em 2012, o Senado argentino, com maioria de 55 votos, nenhum contrário e somente uma abstenção ${ }^{44}$, aprovou a Ley de Identidad de Género.

A Ley de Identidad de Género argentina inova ao entender identidade de gênero "como a experiência interior e individual tal como cada pessoa percebe, que pode obedecer, ou não, ao sexo verificado no momento de seu nascimento, abarcando a vivencia pessoal do corpo "4546,

\footnotetext{
${ }^{42}$ O nome do espaço educacional Mocha Celis foi escolhido em homenagem prestada à travesti argentina Mocha Celis, que ficou conhecida no Bairro de Flores, devido à brutalidade de sua morte em decorrência de três tiros que recebeu na cabeça.

MOLINA, Luana Pagano Peres. A Visibilidade dos/as transexuais da Argentina: A experiência da escola Mocha Celis e a criação da Lei de Identidade de Gênero In: IV Simpósio, Internacional de Educação Sexual: Feminismos, Identidades de Gêneros e Políticas Publicas. 2015, Buenos Aires. Anais... Buenos Aires, 2015. p. 5. Disponível em: $<$ http://www.sies.uem.br/trabalhos/2015/588.pdf>. Acesso em: 15 mai. 2018.

${ }^{43}$ ARGENTINA. Frente Nacional por la Ley de Identidad de Género (FNLIG). Projeto n. 8.126_D-2010. Disponível em: $<$ http://frentenacionaleydeidentidad.blogspot.com.ar>. Acesso em: 15 maì. 2018.

${ }^{44}$ Disponível em:

$<$ http://operamundi.uol.com.br/conteudo/noticias/21754/argentina+aprova+lei+que+permite+mud anca + de + sexo + em + documentos + de + cidadaos + transgeneros.shtml $>$. Acesso em: 20 mai. 2018.

${ }^{45}$ ARTICULO $2^{\circ}$ - Se entiende por identidad de género a la vivencia interna e individual del género tal como cada persona la siente, la cual puede corresponder o no con el sexo asignado al momento del nacimiento, incluyendo la vivencia personal del cuerpo. Esto puede involucrar la modificación de la apariencia o la función corporal a través de medios farmacológicos,
} 
e, ainda, por exigir tão somente a manifestação pessoal e formal do indivíduo com idade mínima comprovada de 18 (dezoito) anos perante o Registro Nacional de Pessoas acerca da sua auto percepção de gênero ${ }^{4748}$, para que seja possível a retificação dos registros civis - sexo, prenome e foto - e o acesso a tratamentos hormonais e cirurgias transgenitalizadoras. Isto é, inova por possibilitar aos indivíduos transgêneros o pleno exercício do direito à autodeterminação.

Ressalta-se que, no ato de manifestação e ao longo de todo o procedimento perante o Registro Nacional de Pessoas, não será exigido qualquer tipo de tratamento hormonal, psicológico ou médico, incluindo-se cirurgias transgenitalizadoras. Isso porque, na forma do artigo $2^{\circ}$ da Ley de Identidad de Género, as manifestações de gênero devem ser vivenciadas livremente:

Esto puede involucrar la modificación de la apariencia o la función corporal a través de medios farmacológicos, quirúrgicos o de otra índole, siempre que ello sea libremente escogido. También incluye otras expresiones de género, como la vestimenta, el modo de hablar y los modales. (ARTIGO $\left.2^{\circ}\right)^{49}$.

quirúrgicos o de otra indole, siempre que ello sea libremente escogido. También incluye otras expresiones de género, como la vestimenta, el modo de hablar y los modales.

ARGENTINA. Ley n. 26.743 de mayo de 2012. Art. 2º . Acesso em: 13 mai. 2018.

${ }^{46}$ Definição sobre identidade de gênero primeiramente expressa no documento dos princípios de Yogyakarta. Disponível em:

$<$ http://www.clam.org.br/uploads/conteudo/principios_de_yogyakarta.pdf> Acesso em: 23 mai. 2018.

${ }^{47}$ ARTICULO $3^{\circ}$.- Toda persona podrá solicitar la rectificación registral del sexo, y el cambio de nombre de pila e imagen, cuando no coincidan con su identidad de género autopercibida.

ARGENTINA. Ley n. 26.743 de mayo de 2012. Art. 3º. Acesso em: 13 mai. 2018.

${ }^{48}$ ARTICULO $4^{\circ}$ - Toda persona que solicite la rectificación registral del sexo, el cambio de nombre de pila e imagen, en virtud de la presente ley, deberá observar los siguientes requisitos: 1. Acreditar la edad mínima de dieciocho (18) años de edad, con excepción de lo establecido en el artículo $5^{\circ}$ de la presente ley. 2. Presentar ante el Registro Nacional de las Personas o sus oficinas seccionales correspondientes, una solicitud manifestando encontrarse amparada por la presente ley, requiriendo la rectificación registral de la partida de nacimiento y el nuevo documento nacional de identidad correspondiente, conservándose el número original. 3. Expresar el nuevo nombre de pila elegido con el que solicita inscribirse. En ningún caso será requisito acreditar intervención quirúrgica por reasignación genital total o parcial, ni acreditar terapias hormonales u otro tratamiento psicológico o médico.

ARGENTINA. Ley n. 26.743 de mayo de 2012. Art. 4º. Acesso em: 13 mai. 2018.

${ }^{49}$ Tradução livre: Isso pode envolver a modificação da aparência ou da função corporal, por meios farmacológicos, cirúrgicos ou outros, desde que isso seja escolhido livremente. Também inclui outras expressões de gênero, como roupas, modo de falar e os modos. 
Ademais, para acesso ao tratamento hormonal e a para realização de cirurgia transgenitalizadora, conforme será abordado oportunamente, também não se faz necessário qualquer tipo de autorização judicial e administrativa, bem como de acompanhamento médico probatório.

A existência de um pressuposto único - a autopercepção do indivíduo - garante a esse diploma legal a qualidade de grande marco mundial na luta pela diversidade sexual e de gênero. Contudo, como será demonstrado a seguir, a Ley de Identidad de Género inova, também, em inúmeros outros sentidos, sendo responsável por consequências extremamente positivas na comunidade dos indivíduos transgêneros.

\subsubsection{Análise dos Principais Aspectos}

Como mencionado, na forma do artigo $4^{\circ}$ da Ley de Identidad de Género, os requisitos para a retificação do sexo, prenome e imagem nos registros civis, são, em síntese, a apresentação por indivíduo maior de idade de requerimento de retificação registral perante o Registro Nacional de Pessoas e a indicação do prenome desejado. Contudo, a Ley de Identidad de Género também autoriza e dispõe sobre retificação do registro civil daqueles indivíduos que ainda não alcançaram a maior idade.

$\mathrm{Na}$ forma do artigo $5^{\mathrm{o} 50}$, no caso dos indivíduos menores de dezoito anos, o requerimento de retificação registral deverá ser efetuado através dos seus representantes legais e com manifestação expressa do menor, tendo em

\footnotetext{
${ }^{50}$ ARTICULO $5^{\circ}$.- Con relación a las personas menores de dieciocho (18) años de edad la solicitud del trámite a que refiere el artículo $4^{\circ}$ deberá ser efectuada a través de sus representantes legales y con expresa conformidad del menor, teniendo en cuenta los principios de capacidad progresiva e interés superior del niño/a de acuerdo con lo estipulado en la Convención sobre los Derechos del Niño y en la Ley 26.061 de protección integral de los derechos de niñas, niños y adolescentes. Asimismo, la persona menor de edad deberá contar con la asistencia del abogado del niño prevista en el artículo 27 de la Ley 26.061

Cuando por cualquier causa se niegue o sea imposible obtener el consentimiento de alguno/a de los/as representantes legales del menor de edad, se podrá recurrir a la vía sumarísima para que los/as jueces/zas correspondientes resuelvan, teniendo en cuenta los principios de capacidad progresiva e interés superior del niño/a de acuerdo con lo estipulado en la Convención sobre los Derechos del Niño y en la Ley 26.061 de protección integral de los derechos de niñas, niños y adolescentes.
}

ARGENTINA. Ley n. 26.743 de mayo de 2012. Art. 5. Acesso em: 13 mai. 2018. 
conta os princípios da capacidade progressiva e do interesse superior das crianças, na forma do estipulado na Convenção sobre os Direitos das Crianças e previsto na Lei Argentina n. 26.061 (Lei de Proteção Integral das Crianças e dos Adolescentes). Ademais, ainda que o menor esteja devidamente representado por seus representantes legais, o procedimento de retificação registral deverá ser acompanhado por advogado especializado, em atendimento ao artigo 27 da Lei Argentina n. 26.061 ${ }^{51}$.

Ressalta-se que, na hipótese de não ser possível obter o consentimento de algum dos representantes legais do menor por qualquer motivo, poderá recorrer-se ao poder judiciário, que decidirá de acordo com os princípios decorrentes da Lei Argentina n. 26.061 e com a Convenção sobre os Direitos das Crianças.

O trâmite posterior à apresentação do requerimento de retificação registral está previsto no artigo $6^{052}$, segundo o qual todos os procedimentos de retificação de registro são gratuitos e dispensam a intermediação de autoridades, bem como decisões administrativas e/ou judiciais, pareceres de equipe multidisciplinar, laudo médico ou provas de acompanhamento

\footnotetext{
${ }^{51}$ ARTICULO 27․ - GARANTIAS MINIMAS DE PROCEDIMIENTO. GARANTIAS EN LOS PROCEDIMIENTOS JUDICIALES O ADMINISTRATIVOS. Los Organismos del Estado deberán garantizar a las niñas, niños y adolescentes en cualquier procedimiento judicial o administrativo que los afecte, además de todos aquellos derechos contemplados en la Constitución Nacional, la Convención sobre los Derechos del Niño, en los tratados internacionales ratificados por la Nación Argentina y en las leyes que en su consecuencia se dicten, los siguientes derechos y garantias: (...) c) A ser asistido por un letrado preferentemente especializado en niñez y adolescencia desde el inicio del procedimiento judicial o administrativo que lo incluya. En caso de carecer de recursos económicos el Estado deberá asignarle de oficio un letrado que lo patrocine.

ARGENTINA. Ley n. 26.743 de mayo de 2012. Art. 27. Acesso em: 13 mai. 2018.

${ }^{52}$ ARTICULO $6^{\circ}$.- Cumplidos los requisitos establecidos en los artículos $4^{\circ}$ y $5^{\circ}$, el/ la oficial público procederá, sin necesidad de ningún trámite judicial o administrativo, a notificar de oficio la rectificación de sexo y cambio de nombre de pila al Registro Civil de la jurisdicción donde fue asentada el acta de nacimiento para que proceda a emitir una nueva partida de nacimiento ajustándola a dichos cambios, y a expedirle un nuevo documento nacional de identidad que refleje la rectificación registral del sexo y el nuevo nombre de pila. Se prohibe cualquier referencia a la presente ley en la partida de nacimiento rectificada y en el documento nacional de identidad expedido en virtud de la misma. Los trámites para la rectificación registral previstos en la presente ley son gratuitos, personales y no será necesaria la intermediación de ningún gestor o abogado.

Ibid., Acesso em: 13 mai. 2018.
} 
psicológico daqueles que não se adequam a cisgeneridade ${ }^{53}$. Note-se, contudo, que, após a realização da retificação registral, esta somente poderá ser novamente alterada mediante decisão judicial ${ }^{54}$.

Ainda na forma do artigo $6^{\circ}$, proíbe-se qualquer referência à realização de retificação registral e/ou a própria lei nos registros civis, ou seja, na certidão de nascimento e no documento de identidade. A confidencialidade das informações é corroborada pelo artigo $9^{055}$, segundo o qual a certidão de nascimento original somente poderá ser acessada por aqueles com autorização do indivíduo ou por meio de decisão judicial fundamentada.

Após a efetuação da retificação registral, caberá ao próprio Registro Nacional de Pessoas comunicar aos demais órgãos necessários, como, por exemplo, a Secretaria de Registro Eleitoral, acerca das alterações realizadas ${ }^{56}$.

Os efeitos da retificação do sexo e do prenome nos registros civis serão oponíveis perante terceiros desde o momento em que esta for efetuada, sendo certo que será mantida a titularidade de todos os direitos e obrigações jurídicas anteriores a esta modificação, inclusive aquelas

\footnotetext{
53 "Chamamos de cisgênero, ou de "cis", as pessoas que se identificam com o gênero que lhes foi atribuído quando ao nascimento".

JESUS, Jaqueline Gomes de. Orientações sobre identidade de gênero: conceitos e termos. $2^{\mathrm{a}}$ ed. Brasília, 2012. p. 7-12. Disponível em:

$<$ https://issuu.com/jaquelinejesus/docs/orienta_es_sobre_identidade_de_g_nero_conceitos_>. Acesso em: 15 mai. 2018.

${ }^{54}$ ARTICULO $8^{\circ}$.- La rectificación registral conforme la presente ley, una vez realizada, sólo podrá ser nuevamente modificada con autorización judicial.

ARGENTINA. Ley n. 26.743 de mayo de 2012. Art. 8º. Acesso em: 13 mai. 2018.

${ }^{55}$ ARTICULO 9०.- Sólo tendrán acceso al acta de nacimiento originaria quienes cuenten con autorización del/la titular de la misma o con orden judicial por escrito y fundada. No se dará publicidad a la rectificación registral de sexo y cambio de nombre de pila en ningún caso, salvo autorización del/la titular de los datos. Se omitirá la publicación en los diarios a que se refiere el artículo 17 de la Ley 18.248.

Ibid., Art. $9^{\circ}$. Acesso em: 13 mai. 2018.

${ }^{56}$ ARTICULO $10^{\circ}$.- El Registro Nacional de las Personas informará el cambio de documento nacional de identidad al Registro Nacional de Reincidencia, a la Secretaría del Registro Electoral correspondiente para la corrección del padrón electoral y a los organismos que reglamentariamente se determine, debiendo incluirse aquéllos que puedan tener información sobre medidas precautorias existentes a nombre del interesado. Ibid., Art. 10 . Acesso em: 13 mai. 2018.
} 
provenientes das relações próprias do direito de família, mantendo-se inalteráveis eventuais adoções realizadas ${ }^{57}$.

Por fim, cabe mencionar que a Ley de Identidad de Género garante o exercício do livre desenvolvimento pessoal e gozo completo à saúde, estabelecendo em seu artigo 11 a possibilidade de acesso a intervenções cirúrgicas totais e parciais e/ou a tratamentos integrais hormonais para adequação do corpo, sem que para tanto seja necessário requerer autorização judicial ou administrativa. Dispõe, ainda, que, para acessar o tratamento hormonal, não será necessário provar a realização de intervenção cirúrgica, sendo necessário, tão somente, o consentimento do indivíduo. Para tal fim, em seu artigo $14^{\circ}$, revoga o parágrafo $4^{\circ}$ do artigo $19^{58}$, da Ley 17.132 que dispõe a respeito do exercício da medicina, odontoligia e práticas auxiliares.

O décimo primeiro artigo desta Lei também prevê a realização deste procedimento no caso de menores de idade, o que deve ser feito conforme o protocolo previsto no artigo $5^{\circ}$, que trata sobre a retificação registral. Esse artigo recepciona também que os setores público e privado de saúde devem observar de forma permanente os direitos reconhecidos por este diploma legal, sendo certo que os serviços de saúde devem estar contemplados no Plan Médico Obligatorio $(P M O)^{59}$.

\footnotetext{
${ }^{57}$ ARTICULO $7^{\circ}$.- Los efectos de la rectificación del sexo y el/los nombre/s de pila, realizados en virtud de la presente ley serán oponibles a terceros desde el momento de su inscripción en el/los registro/s. La rectificación registral no alterará la titularidad de los derechos y obligaciones jurídicas que pudieran corresponder a la persona con anterioridad a la inscripción del cambio registral, ni las provenientes de las relaciones propias del derecho de familia en todos sus órdenes y grados, las que se mantendrán inmodificables, incluida la adopción. En todos los casos será relevante el número de documento nacional de identidad de la persona, por sobre el nombre de pila o apariencia morfológica de la persona.

ARGENTINA. Ley n. 26.743 de mayo de 2012. Acesso em: 13 mai. 2018.

${ }^{58}$ Artículo 19:Los profesionales que ejerzan la medicina están, sin perjuicio de lo que establezcan las demás disposiciones legales vigentes, obligados a: [...] no llevar a cabo intervenciones quirúrgicas que modifiquen el sexo del enfermo, salvo que sean efectuadas con posterioridad a una autorización judicial;

ARGENTINA. Ley n. 17.132 de janeiro de 1967. Art. 19º Disponível em:

$<$ http://servicios.infoleg.gob.ar/infolegInternet/anexos/1500019999/19429/norma.htm>. Acesso em: 20 mai. 2018.

${ }^{59}$ Tradução livre: Plano Médico Obrigatório: O Programa de Emergência Médica de Emergência (PMOE - Res.201 / 02 MS) estabelece os benefícios básicos essenciais que os Assistentes Sociais
} 


\subsubsection{Comentários Conclusivos}

Após a análise pormenorizada das previsões constantes na Ley de Identidad de Género, nota-se o pioneirismo e a inovação deste diploma legal ao possibilitar o pleno exercício do direito de autodeterminação dos indivíduos, fato este que se torna ainda mais marcante, quando se compara esta Lei a diplomas legais anteriores e/ou provenientes de outros países, como Espanha, Portugal, Uruguai e Inglaterra ${ }^{60}$.

Isso porque, nesses países, para que seja autorizada a retificação dos registros civis, são estipulados alguns pré-requisitos, tais como: a realização de tratamentos hormonais, a apresentação de provas de que o indivíduo vive de acordo com o gênero que se autodetermina e de relatório médico assinado por profissionais qualificados no âmbito da saúde, assim como a necessidade de decisão judicial ou administrativa, a depender do caso.

Ressalta-se, de igual maneira, o cuidado do legislador argentino ao determinar a manutenção do número do documento de identidade nacional, mesmo após a alteração do nome e do sexo, fato este que demonstra a maior importância conferida ao número do documento para fins de identificação de um indivíduo enquanto cidadão ${ }^{61} \mathrm{e}$, por consequência, a menor importância concedida ao gênero e o sexo. Em igual sentido, verifica-se a valorização do cidadão na manutenção dos direitos e obrigações contraídos pelo indivíduo, bem como de todas as obrigações legais, antecedentes criminais, aspectos próprios do direito de família e aspectos da vida civil em todas as ordens e diplomas.

e de Seguros devem garantir a toda a população beneficiária. Este programa é válido até 31 de dezembro de 2003

Decreto 2724/02. Disponível em: <https://www.sssalud.gob.ar/pmo/res_201.php>. Acesso em: 15 mai. 2018.

${ }^{60}$ PEREIRA, Júlia Mendes. O reconhecimento da identidade de gênero como processo emancipatório: percursos legais. Disponível em: <http://www.acomuna.net/index.php/contracorrente/4625-o-reconhecimento-da-identidade-de-genero-como-processo-emancipatoriopercursos-legais>. Acesso em: 15 mai. 2018.

${ }^{61}$ ARGENTINA. Ley n. 26.743 de mayo de 2012. Art. 4. Acesso em: 13 mai. 2018. 
Outro ponto que merece especial destaque é o zelo do Estado pela atualização das informações constantes nos registros civis e o dever deste de notificar os demais entes do governo ${ }^{62}$. Nas palavras de Carolina Grant:

\begin{abstract}
A própria lei, em seu art. 10, determina que o Registro Nacional das Pessoas deverá informar a mudança no documento nacional de identidade ao Registro Nacional de Reincidência, à Secretaria de Registro Eleitoral correspondente e a outras instâncias ou instituições que forem consideradas necessárias por regulamento; ou seja, cria mecanismos para evitar fraudes e colaborar para que o reconhecimento da identidade de gênero do indivíduo não inviabilize a organização estatal no que diz respeito à persecução criminal, cumprimento de obrigações eleitorais, dentre outras atividades que exijam a identificação do sujeito perante o Estado. Tudo isso sem ferir a confidencialidade, privacidade e intimidade da pessoa trans ${ }^{63}$.
\end{abstract}

Diante de todo o acima exposto, verifica-se que a Ley de Identidad de Género, além de ser o primeiro diploma legal a possibilitar o pleno exercício do direito a autodeterminação aos indivíduos, rompendo com ideias de determinismo natural, com a ideologia heteronormativa e com a ideia de patologização da transexualidade, merece destaque pelo zelo dos seus legisladores ao tratar dos mais variados aspectos, como é o caso da manutenção do número de identidade, garantindo a promoção de todo o rol de direitos fundamentais, quais sejam: identidade, educação, trabalho, saúde, cultura.

Esse instituto jurídico, extensivo aos estrangeiros residentes no país ${ }^{64}$ e responsável por elevar o transgênero à condição de cidadão, em razão de todas as características acima expostas, possui poder multiplicador de avanços nas questões humanitárias para além das fronteiras da Argentina, impulsionando a criação de diplomas legais semelhantes e, ainda, o ativismo judicial em consonância com os direitos por ela reconhecidos.

\footnotetext{
${ }^{62}$ ARGENTINA. Ley n. 26.743 de mayo de 2012. Art. 10. Acesso em: 13 mai. 2018.

${ }^{63}$ GRANT, Carolina. Direito e gênero em trânsito: Quando corpos e gêneros em trânsito obrigam o Direito - uma análise crítica da ley de identidad de género argentina e do PL 5002/2013 a partir dos estudos queer. p. 24. Disponível em: $<$ http://www.publicadireito.com.br/artigos/?cod=f01287d4b412a2b1>. Acesso em: 15 mai. 2018. ${ }^{64}$ SILVA, 2016, p. 9.
} 
O Projeto de Lei de n. 5002/13, conhecido como o PL João Nery ${ }^{65}$, inspirado no modelo argentino, é um exemplo do poder multiplicador da Ley de Identidad de Género para além das fronteiras do seu país. Esse Projeto de Lei será analisado ao longo do terceiro e último capítulo do presente trabalho, ao final do qual se concluirá acerca da latente necessidade de sua aprovação, para que, finalmente, o ordenamento jurídico brasileiro venha a conferir aos seus cidadãos o direito ao exercício de todos os direitos que lhes são fundamentais.

${ }^{65} \mathrm{O}$ nome conferido ao PL foi em homenagem ao primeiro transexual brasileiro a realizar a cirurgia de redesignação sexual. 


\section{CAPÍTULO 3 - O DIREITO BRASILEIRO E OS TRANSGÊNEROS}

O princípio da dignidade da pessoa humana ${ }^{66}$, previsto de forma expressa no artigo $1^{\circ}$, inciso III, da Constituição da República Federativa do Brasil de 1988 (CRFB/88) e, de forma não expressa, em vários outros momentos no referido diploma legal, como, por exemplo, no artigo $5^{\circ}$, incisos III - não submissão à tortura -, VI - inviolabilidade da liberdade de consciência e de crença - e X - inviolabilidade da vida privada, honra e imagem -, constitui um dos fundamentos do Estado Democrático de Direito, sendo sua principal finalidade a preservação e valorização do homem, garantindo-lhe sua liberdade individual e personalidade.

Esse princípio é o alicerce de todo o ordenamento jurídico pátrio e internacional. Nas palavras de Ana Paula Barcellos:

Lembre-se, por muito importante, que o princípio da dignidade da pessoa humana deverá presidir a interpretação de todas essas normas e do texto constitucional como um todo ${ }^{67}$.

Não obstante, na qualidade de valor a ser observado na interpretação e aplicação do direito, este princípio está previsto em incontáveis Constituições Modernas Ocidentais e Declarações Internacionais ${ }^{68}$.

O sujeito desse princípio - a "pessoa universal" -, apesar de toda a generalidade e abstração, não se mostrou suficiente para a tutela dos direitos dos

\footnotetext{
${ }^{66}$ Ingo Wolfgang Sarlet, em "A Eficácia dos Direitos Fundamentais", define dignidade da pessoa humana: Temos por dignidade da pessoa humana a qualidade intrínseca e distintiva de cada ser humano que o faz merecedor do mesmo respeito e consideração por parte do Estado e da comunidade, implicando, neste sentido, um complexo de direitos e deveres fundamentais que assegurem a pessoa tanto contra todo e qualquer ato de cunho degradante e desumano, como venham a lhe garantir condições essenciais mínimas para uma vida saudável, além de propiciar e promover sua participação ativa co-responsável nos destinos da própria existência e da vida em comunhão dos demais seres humanos.

SARLET, Ingo Wolfgang. A eficácia dos direitos fundamentais. $2^{\mathrm{a}}$ ed. Porto Alegre: Livraria do Advogado, 2001. p. 60.

${ }^{67}$ BARCELLOS, Ana Paula. p. 181-182. Normatividade dos Princípiios e o Principio da Dignidade da Pessoa Humana na Constituição de 1988. Disponível em: < file:///Users/administrator/Downloads/4758893204-1-PB.pdf>. Acesso em: 02 jun. 2018.

${ }^{68}$ GONÇALVES, Camila de Jesus Mello. Transexualidade e direitos humanos: o reconhecimento da identidade de gênero entre os direitos da personalidade.Curitiba: Juruá, 2014. p. 19.
} 
transgêneros ${ }^{69}$, o que, no Brasil, constata-se através da precariedade do tratamento jurídico a estes indivíduos, que, de forma exemplificativa, reflete-se na dificuldade de acesso às cirurgias de transgenitalização e de alteração do registro civil.

Ao longo deste capítulo, serão abordadas as questões indicadas acima e, ao final, será analisado o Projeto de Lei n. 5002/2013, de autoria dos Deputados Federais Jean Wyllys e Érika Kokay, que dispõe sobre o direito à identidade de gênero e altera o artigo 58 da Lei 6.015 de 1973, levando em consideração principalmente a Lei de Identidade de Gênero da Argentina, que foi objeto de análise no capítulo anterior e serviu de espelho para elaboração do referido projeto de lei.

\subsection{Sobre as Cirurgias de Transgenitalização}

Conforme já fora apontado ao longo do presente trabalho, apesar de os termos "transexual" e "transgênero" serem utilizados como sinônimos, na prática, existem diferenças entre estas definições. Isso porque, embora em ambos os casos os indivíduos não se identifiquem com o seu gênero biológico, no caso dos transexuais, o sentimento de não pertencimento é tão intenso que há a necessidade latente de se alterar a sua constituição biológica, o que pode ser concretizado através da realização da cirurgia de mudança de sexo (cirurgia de transgenitalização).

A cirurgia de transgenitalização evoluiu sobremaneira ao longo dos últimos anos, o que, infelizmente, não pode ser afirmado em relação ao ordenamento jurídico brasileiro, como bem asseverou a Desembargadora Maria Berenice Dias:

Com a evolução das técnicas cirúrgicas, tornou-se possível mudar a morfologia sexual externa, meio que começou a ser utilizado para encontrar a equiparação da aparência ao gênero que se identifica. Dito avanço no campo médico, entretanto, não foi acompanhado pela legislação, uma vez que nenhuma previsão legal existia a regular a realização da cirurgia. Essa omissão levava a classe médica a uma problemática ético-

${ }^{69}$ GONÇALVES, 2014, p. 19. 
jurídica e a questionamentos sobre a natureza das intervenções cirúrgicas e a possibilidade de sua realização. (...) por intermédio da Resolução n. 1.482, de 10/09/97, o Conselho Federal de Medicina autorizou, a título excepcional, a cirurgia de transexuais. Considerando ser o paciente portador de desvio patológico permanente de identidade sexual, com rejeição do fenótipo, foi reconhecido que a transformação é terapêutica e, não havendo lei que a defina como crime, inexiste afronta à ética médica $^{70}$.

Foi somente no ano de 2006, que foi disponibilizado pelo Conselho da Justiça Federal o Enunciado de n. 276, que fornece orientações sobre a aplicação das disposições constante do artigo 13 do Código Civil de 2002:

Art. 13. Salvo por exigência médica, é defeso o ato de disposição do próprio corpo, quando importar diminuição permanente da integridade física, ou contrariar os bons costumes $^{71}$.

Prevendo que o referido artigo:

Ao permitir a disposição do próprio corpo por exigência médica, autoriza as cirurgias de transgenitalização, em conformidade com os procedimentos estabelecidos pelo Conselho Federal de Medicina, e a consequente alteração do prenome e do sexo no Registro Civil ${ }^{72}$.

O Enunciado de n. 276 fez referência à Resolução n. $1.482^{73}$, citada pela Desembargadora Maria Berenice Dias, que autorizou a realização de cirurgia de transgenitalização, a título experimental, nos hospitais públicos credenciados. Além de a referida resolução, que, atualmente, está revogada, dispor sobre a necessidade de o paciente ser portador de "desvio permanente de identidade sexual, com rejeição do fenótipo e tendência à auto mutilição e ou auto extermínio", estabelecia a idade mínima de 21 anos e a imprescindibilidade de avaliação do paciente por equipe multidisciplinar, de modo a confirmar se o paciente é portador do "transexualismo".

\footnotetext{
${ }^{70}$ DIAS. Maria Berenice. Transexualidade e o Direito de Casar. Disponível em:

$<$ http://www.mariaberenice.com.br/manager/arq/(cod2_788)1_transexualidade_e_o_direito_de_casar.pd f.>. Acesso em: 16 mai. 2018.

${ }^{71}$ BRASIL. Lei n. 10.406, de 10 de janeiro de 2002. Acesso em: 02 jun. 2018.

72 BRASIL. Enunciado 276, de 2006. Acesso em: 02 jun. 2018.

${ }^{73}$ Resolução n. 1482/1997 do Conselho Federal de Medicina. Disponível em:

$<$ http://www.portalmedico.org.br/resolucoes/cfm/1997/1482_1997.htm>. Acesso em: 16 mai. 2018.
} 
A Resolução n. 1.482/1997 foi revogada pela Resolução n. $1.652^{74}$, que, em razão do então "estágio atual dos procedimentos de seleção e tratamento dos casos de transexualimo, com evolução decorrente dos critérios estabelecidos na Resolução CFM n. 1482/97 e do trabalho das instituições ali previstas", autorizou a cirurgia de transgenitalização do tipo neocolpovulvoplastia e/ou procedimentos complementares sobre gônadas e caracteres sexuais secundários como tratamento dos casos de "transexualismo" - art. $1^{\circ}$-, mantendo, ainda a título experimental, a realização de cirurgia do tipo neofaloplastia - art. $2^{\circ}$.

Posteriormente, em 2010, foi publicada nova resolução pelo Conselho Federal de Medicina, qual seja: a Resolução n. 1.955/2010 $0^{75}$. Essa resolução regulamenta de modo completo a cirurgia de transgenitalização, revogando a Resolução n. 1.652/2002 e aprimorando requisitos relacionados a esta cirurgia ainda assim, a neofaloplastia foi mantida apenas a título experimental.

No âmbito legislativo, notaram-se avanços tão somente a partir do ano de 2008 com a publicação da Portaria n. 1.707 do Ministério da Saúde ${ }^{76}$, responsável por incluir a cirurgia de transgenitalização na listagem dos procedimentos cirúrgicos do Sistema Único de Saúde - SUS. Na referida portaria, a orientação sexual e a identidade de gênero foram tratadas como questões de saúde, em razão das implicações sexuais e da necessidade de se combater o estigma e a descriminação vivenciada pelos GLBTT $^{77}$.

Em 2013, em atendimento à decisão judicial proferida no dia 13 de setembro de 2013 em sede de execução na Ação Civil Pública n. 2001.71.00.026279-9/RS, que determinou ao Ministério da Saúde o cumprimento integral, no prazo de trinta dias, das medidas necessárias para possibilitar a realização no SUS de todos os procedimentos médicos para garantir a cirurgia de

\footnotetext{
${ }^{74}$ Resolução n. 1652/2002 do Conselho Federal de Medicina. Disponível em: $<$ http://www.portalmedico.org.br/resolucoes/cfm/2002/1652_2002.htm>. Acesso em: 16 mai. 2018.

${ }^{75}$ Resolução n. 1955/2010 do Conselho Federal de Medicina. Disponível em:

$<\mathrm{http}$ //www.portalmedico.org.br/resolucoes/CFM/2010/1955_2010.htm>. Acesso em: 16 mai. 2018.

${ }^{76}$ Portaria n. 1.707/2008 do Ministério da Saúde. Disponível em:

$<$ http://bvsms.saude.gov.br/bvs/saudelegis/gm/2008/prt1707_18_08_2008.html $>$. Acesso em: 16 mai. 2018.

${ }^{77}$ GLBTT define o grupo constituído por gays, lésbicas, bissexuais, travestis e transexuais.
} 
transgenitalização e a readequação sexual no processo transexualizador ${ }^{78}$, foi publicada nova Portaria de n. 2.803/2013, revogando a Portaria n. 1.707/2008.

Essa portaria estipulou, em seu artigo $2^{\circ}$, as diretrizes de assistência ao usuário do SUS com demanda pelo processo transexualizador, como, por exemplo, a "integralidade da atenção a transexuais e travestis" e a:

Integração com as ações e serviços em atendimento ao processo transexualizador, tendo como porta de entrada a atenção básica em saúde, incluindo-se acolhimento e humanização do atendimento livre de descriminação, por meio da sensibilização dos trabalhadores e demais usuários da unidade de saúde para o respeito às diferenças e à dignidade humana, em todos os níveis de atenção ${ }^{79}$.

Em que pese os avanços no campo médico, legislativo e judiciário acerca do tema e da conquista da possibilidade de realização da cirurgia de transgenitalização através do Sistema Único de Saúde, na prática, o indivíduo transexual é submetido a um acompanhamento médico por uma equipe multidisciplinar por, no mínimo, 02 (dois) anos, sendo certo que este procedimento cirúrgico somente será autorizado nos casos em que o paciente for enquadrado como portador do transtorno de disforia de gênero. Isso sem contar a fila de espera para realização da cirurgia, que se dá em reflexo à alta demanda e ao baixo número de unidades do SUS capacitadas para esse tipo de atendimento $^{8081}$.

\footnotetext{
${ }^{78} \mathrm{O}$ "processo transexualizador", como é chamado no Brasil, inclui vários tratamentos e procedimentos que nem sempre vêm juntos. Por exemplo: uso de bloqueadores de hormônios, terapia com hormônios, cirurgias plásticas, implante de seios ou de próteses penianas, depilação a laser, etc. Algumas pessoas pensam apenas na vaginoplastia (a cirurgia que consiste, muito resumida e simplificadamente, na retirada do pênis e dos testículos e na abertura de uma vagina), que é realizada pelas pessoas trans com identidade de gênero feminina, mas isso é apenas uma parte (geralmente uma das últimas, nos casos em que é praticada, que não são todos) do processo transexualizador.

WYLLYS, Jean. Esclarecimentos sobre o PL 5002/2013 "João Nery", no quetange ao direito à identidade de gênero de pessoas menores de 18 anos de idade. Disponível em: $<$ http://jeanwyllys.com.br/wp/esclarecimentos-sobre-opl-50022013-joao-nery-no-que-tange-ao-direito-aidentidade-de-genero-depessoas-menores-de-18-anos-de-idade>. Acesso em: 20 mai. 2018.

${ }^{79}$ BRASIL. Ministério da Saúde. Portaria n. 2.803/2013. Disponível em:

<http://bvsms.saude.gov.br/bvs/saudelegis/gm/2013/prt2803_19_11_2013.html>. Acesso em: 16 mai. 2018.

${ }^{80}$ CARTA CAPITAL. Fila para cirurgia de resignação sexual pode passar de dez anos. Disponível em: $<$ https://www.cartacapital.com.br/diversidade/Fila-para-cirurgia-de-redesignacao-sexual-pode-passar-dedez-anos>. Acesso em: 17 mai. 2018.

${ }^{81}$ Reportagem do sítio eletrônico Correio 24 Horas, segundo a qual, em 2016, apenas 5 hospitais no Brasil faziam cirurgia transgenital pelo SUS.
} 
O que se verifica é que, apesar das incontestáveis conquistas alcançadas, esses indivíduos ainda são considerados portadores de uma patologia, sendo, inclusive, o diagnóstico desta por uma equipe médica multidisciplinar após longo período probatório condição essencial para autorização e realização da cirurgia de transgenitalização. Nesse sentido, é latente a inobservância do direito destes indivíduos à sua própria autodeterminação, no que se refere ao seu gênero e sexo.

Nas palavras de Carolina Souza Dias Gerassi e Patricia Cristina Brasil:

Percebe-se, assim, que o direito à adequação do sexo nos âmbitos físico e jurídico, como posto em nosso sistema normativo, não decorre simplesmente da apropriação do direito à autodeterminação de identidade sexual no rol dos direitos e garantias fundamentais. Contrario senso qualquer indivíduo estaria autorizado a se submeter aos procedimentos clínicos e cirúrgicos de alteração de sexo biológico, bem como requerer a retificação de gênero e nome no registro civil ${ }^{82}$.

Conclui-se que, na prática, o que se tem é uma nítida contradição entre os direitos inerentes a todo e qualquer cidadão pertencente a um Estado Democrático de Direito - igualdade, liberdade, cidadania - e os princípios da regulação da desigualdade e exclusão, o que se reflete em políticas públicas voltadas à autoderterminação de gênero, que, por um lado, a reconhecem como direito fundamental e, por outro, respaldam-se na excludente conceituação de patologia ${ }^{83}$.

\subsection{Direito ao Registro Civil}

Apesar de toda a problemática relativa ao acesso à cirurgia de transgenitalização abordada no tópico acima, o grande obstáculo enfrentado pelos transgêneros está na alteração do seu registro civil, de modo a alcançar a completa satisfação pessoal, em observância aos seus direitos da personalidade e ao princípio da dignidade da pessoa humana.

\footnotetext{
Disponível em: <https:/www.correio24horas.com.br/noticia/nid/apenas-cinco-hospitais-fazem-cirurgiatransgenital-pelo-sus-no-brasil/>. Acesso em: 17 mai. 2018.

${ }^{82}$ Disponível em: <http://publicadireito.com.br/artigos/?cod=56dbbe315d23b256>. Acesso em: 18 mai. 2018.

${ }^{83}$ Ibid., Acesso em: 17 mai. 2018.
} 
Isso porque o ordenamento jurídico pátrio baseia-se no princípio da imutabilidade do nome. Essa imutabilidade é relativizada pelos artigos 58 e 55 da Lei de Registros Públicos ${ }^{84}$, isto é, pela viabilidade de retificação do nome por apelidos públicos notórios e de alteração quando este for suscetível de expor o indivíduo a situação vexatória.

Como se verifica, a princípio, a alteração do registro civil por indivíduos transgêneros, que realizaram - ou não - a cirurgia de transgenitalização, não se enquadra como uma das hipóteses de flexibilização do referido princípio. Por esse motivo, desde que o Conselho Federal de Medicina passou a autorizar a realização da cirurgia de transgenitalização (Resolução 1.482/1997) até o julgamento da Ação Direta de Inconstitucionalidade n. 4275, que será analisada oportunamente ao longo deste trabalho, para que esses indivíduos pudessem equiparar seu registro civil - isto é, seu nome - à sua identidade de gênero, foi necessário recorrer ao poder judiciário.

A partir da análise da jurisprudência dos Tribunais de Justiça, verifica-se que, com base no princípio da dignidade humana e da não discriminação (CRFB/88, art. $1^{\circ}$, III e $3^{\circ}$, IV), bem como diante da existência de justo motivo para alteração do nome, há a flexibilização do princípio da imutabilidade. Em 2007, o Superior Tribunal de Justiça julgou pela primeira vez a possibilidade de alteração de prenome e sexo por indivíduo transgênero, que, no caso, havia realizado a cirurgia, o que foi autorizado mediante averbação no registro civil, indicando a alteração do nome e do sexo decorreu de decisão judicial ${ }^{85}$.

\footnotetext{
${ }^{84}$ Art. 55. Quando o declarante não indicar o nome completo, o oficial lançará adiante do prenome escolhido o nome do pai, e na falta, o da mãe, se forem conhecidos e não o impedir a condição de ilegitimidade, salvo reconhecimento no ato. Parágrafo único. Os oficiais do registro civil não registrarão prenomes suscetíveis de expor ao ridículo os seus portadores. Quando os pais não se conformarem com a recusa do oficial, este submeterá por escrito o caso, independente da cobrança de quaisquer emolumentos, à decisão do Juiz competente.

Art. 58. O prenome será definitivo, admitindo-se, todavia, a sua substituição por apelidos públicos notórios. Parágrafo único. A substituição do prenome será ainda admitida em razão de fundada coação ou ameaça decorrente da colaboração com a apuração de crime, por determinação, em sentença, de juiz competente, ouvido o Ministério Público.

BRASIL. Lei $\mathrm{n}^{\circ}$ 6.015, de 31 de dezembro de 1973. Disponível em:

$<\mathrm{http}$ ://www.planalto.gov.br/ccivil_03/Leis/L6015original.htm>. Acesso em: 02 jun. 2018.

${ }^{85}$ REsp 678.933/RS, Rel. Ministro CARLOS ALBERTO MENEZES DIREITO, TERCEIRA TURMA, Julgamento em: 22.03.07, DJ 21.05.07. p. 571.
} 
Posteriormente, em 2009 o Superior Tribunal de Justiça voltou a julgar a matéria, reconhecendo o direito do transexual de alterar seu prenome e o sexo em seu registro civil, sem que, para tanto, fosse necessária qualquer anotação no documento, mas tão somente nos livros cartorários ${ }^{86}$. De acordo com ambos os julgados, a realização de cirurgia de transgenitalização ainda seria um prérequisito para tanto.

Anos mais tarde, em 2014, o Supremo Tribunal Federal reconheceu a repercussão geral do Recurso Extraordinário n. 670422/RS, por meio do qual se discute a possibilidade de alteração do gênero no assento de registro civil, mesmo sem a realização do procedimento cirúrgico de redesignação de sexo, o que teria sido negado em sede de primeira e segunda instância no âmbito da justiça estadual. O recurso ainda não foi julgado, em razão da suspensão do seu julgamento em novembro de 2017.

Até o momento, votaram cinco Ministros, dentre eles o Ministro Relator o Ministro Dias Toffoli, todos a favor do provimento do recurso. Para o Ministro Relator, conforme se afere a partir da análise do seu voto, para o desenvolvimento da personalidade humana, deve-se afastar qualquer óbice jurídico que represente limitação ao exercício pleno pelo ser humano da liberdade de escolha de identidade, orientação e vida sexual, sendo qualquer tratamento jurídico discriminatório sem justificativa constitucional razoável e proporcional.

De acordo com Dias Toffoli, a Lei de Registros Públicos permite a alteração do prenome, uma vez que se constate que o mesmo expõe o seu detentor à situação vexatória, motivo pelo qual a flexibilização do princípio da imutabilidade do nome se aplicaria, também, aos indivíduos transgêneros. Nas palavras do Ministro Relator:

\footnotetext{
${ }^{86}$ REsp 1008398/SP, Rel. Ministra NANCY ANDRIGHI, TERCEIRA TURMA, Julgamento em: 15.10.2009, DJe 18.11.09; e REsp 670422 RG, Rel. Ministro JOÃO OTÁVIO DE NORONHA, QUARTA TURMA, Julgamento em: 10.11.09, DJe 18.12.09.
} 
Diante da situação fática posta no dia a dia das pessoas transexuais ficará evidente sua exposição a eventual discriminação caso seus pleitos de reassentamento não sejam concedidos, violando-se, na espécie, a dignidade da pessoa humana ${ }^{87}$.

No que se refere ao procedimento para alteração do prenome e da classificação do sexo, explicita o Ministro Relator que, em observação aos artigos 98 e 99 da Lei de Registro Civil (n. 6.015/1973) ${ }^{88}$, esta dependeria de decisão judicial meramente declaratória e decorrente do procedimento de jurisdição voluntária. Esse procedimento ocorreria sob sigilo de justiça, de modo a evitar qualquer constrangimento, e não haveria qualquer observação acerca de tal fato nas certidões de registro, além de ser vedada a emissão de certidão de inteiro teor, exceto mediante decisão judicial nesse sentido.

\subsection{Ação Direta de Inconstitucionalidade n. 4275}

Conforme demonstrado o tópico acima, no decorrer dos últimos anos, houve relevante avanço jurisprudencial no que se refere aos direitos dos transexuais, sendo, até então, autorizada alteração do nome e do sexo nos assentamos civis para aqueles indivíduos que já haviam realizado a cirurgia de transgenitalização. Para os indivíduos transgêneros que não haviam realizado a cirurgia (por estar em estágio probatório, na fila de espera ou, ainda, por simplesmente não possuir o desejo de realiza-la), aguardava-se o julgamento do RE n. 670422/RS, acima mencionado, e, também, da Ação Direta de Inconstitucionalidade n. 4275.

A ADI 4275 foi ajuizada pela Procuradora-Geral da República (PGR) em 2009, para que fosse dada interpretação conforme a Constituição Federal ao artigo 58 da Lei 6.015/1973 (Lei de Registros Públicos), "reconhecendo o direito

\footnotetext{
87 Conforme notícia publicada no sítio eletrônico do STF. Disponível em: $<$ http://www.stf.jus.br/portal/cms/verNoticiaDetalhe.asp?idConteudo=362576>. Acesso em: 18 mai. 2018.

${ }^{88}$ Art. 98. A averbação será feita à margem do assento e, quando não houver espaço, no livro corrente, com as notas e remissões recíprocas, que facilitem a busca;

BRASIL. Lei ${ }^{\circ}$ 6.015, de 31 de dezembro de 1973. Acesso em: 02 jun. 2018.

Art. 99. A averbação será feita mediante a indicação minuciosa da sentença ou ato que a determinar. Ibid., Acesso em: 02 jun. 2018.
} 
dos transexuais, que assim o desejarem, à substituição de prenome e sexo no registro civil, independentemente da cirurgia de transgenitalição" ${ }^{\text {" }}$. Com o objetivo de indicar as balizas necessárias para o deferimento do pedido, a PGR sugere que, no caso de ausência de cirurgia de transgenitalização, seja necessário possuir idade igual ou superior a 18 anos, encontrar-se há pelo menos três anos sob a convicção de pertencer ao gênero oposto, ser presumível com alta probabilidade não haverá nova alteração identidade de gênero. Todos esses requisitos devem ser atestados por um grupo de especialistas que avaliem aspectos psicológicos, médicos e sociais.

A petição inicial apresentada pela PGR, que foi instruída com representações da ABGLT - Associação Brasileira de Gays, Lésbicas, Bissexuais, Travestis e Transexuais e pela Articulação Nacional de Travestis e Transexuais, embasa-se na tese de que há um direto fundamental à identidade de gênero, inferido dos princípios da dignidade da pessoa humana (art. $1^{\circ}$, inciso III), da igualdade (art. 5 caput), da vedação de discriminações odiosas (art. $3^{\circ}$, inciso IV), da liberdade (art. 5 , caput), e da privacidade (art. 5 X). Ademais, argumenta que o direito fundamental à identidade de gênero sustenta a exegese de que o art. 58 da Lei 6.015 autoriza mudança de sexo e prenome no registro civil, no caso dos transexuais.

Finalmente, no dia 01 de março de 2018, a ADI foi julgada pelo Supremo Tribunal Federal - STF, que entendeu ser possível a alteração de nome e gênero no assento de registro civil, mesmo sem a realização de procedimento cirúrgico de redesignação de sexo, de tratamentos hormonais ou patologizantes. Todos os ministros reconheceram o direito, sendo certo que a maioria entendeu que, para a alteração, não é necessária autorização judicial ${ }^{90}$. Essa decisão possui efeito erga omnes.

\footnotetext{
${ }^{89}$ Petição Inicial da ADI. p. 01. Disponível em:

$<$ http://www.mpf.mp.br/pgr/copy_of_pdfs/ADI\%204275.pdf/view>. Acesso em: 18 mai. 2018.

${ }^{90}$ Conforme notícia publicada no sítio eletrônico do Superior Tribunal de Justiça. Disponível em: $<$ http://www.stf.jus.br/portal/cms/verNoticiaDetalhe.asp?idConteudo=371085>. Acesso em: 18 mai. 2018.
} 
Merece especial destaque o voto do Ministro Celso de Mello, segundo o qual este julgamento assumiu:

\begin{abstract}
Importância fundamental no processo de ampliação e de consolidação dos direitos fundamentais das pessoas (...) de que todos os seres humanos nascem livres e iguais em dignidade e direitos, pois todos os direitos humanos são universais, interdependentes, indivisíveis e inter-relacionados, sendo certo (...) que a orientação sexual e a identidade de gênero são essenciais à dignidade e humanidade de cada pessoa, não devendo ser motivo de discriminação ou abuso ${ }^{91}$.
\end{abstract}

Afirma o Ministro que, com o julgamento da ADI 4275:

O Brasil dá um passo significativo contra a discriminação e contra o tratamento excludente que tem marginalizado grupos minoritários em nosso País, como a comunidade de transgêneros, o que torna imperioso acolher novos valores e consagrar uma nova concepção de Direito fundada em nova visão de mundo, superando os desafios impostos pela necessidade de mudança de paradigmas, em ordem de viabilizar, como política de Estado, a instauração e a consolidação de uma ordem jurídica genuinamente inclusiva ${ }^{92}$.

Com o referido julgamento, como destacado pelo Ministro Celso Mello em seu voto, foi dado um grande passo para a construção e consolidação de uma ordem jurídica conclusiva, tarefa em relação a qual o Poder Legislativo vem se mostrado contrário, "certamente influenciado por valores e sentimentos prevalecentes na sociedade brasileira" ${ }^{, 93}$.

O posicionamento contrário a este tema por parte do Poder Legislativo, sem sombras de dúvidas, reflete-se lenta tramitação de Projetos de Lei que tenham como objeto os direitos destes indivíduos, como é o caso do Projeto de Lei n. 5002/2013, que dispõe sobre o direito à identidade de gênero e altera o artigo 58 da Lei 6.015 de 1973 e, como será verificado no tópico a seguir, possui grande similaridade com objeto da ADI ora analisada.

\footnotetext{
${ }^{91}$ STF. ADI 4275. Voto Ministro Celso de Mello. Julgamento em: 01 mar 2018. p. 10. Disponível em: $<$ http://www.stf.jus.br/arquivo/cms/noticiaNoticiaStf/anexo/ADI4.275DFVotodoMin.CelsodeMello.pdf $>$. Acesso em: 21 mai. 2018.

92 Ibid., Acesso em: 21 mai. 2018.

${ }^{93}$ STF. ADI 4275, op. cit., Acesso em: 21 mai. 2018.
} 


\subsection{Projeto de Lei n. 5002/2013.}

O Projeto de Lei n. 5002/2013 é resultado da iniciativa dos deputados Jean Wyllys, do Partido do Socialismo e Liberdade - Psol, e Érika Kokay, do Partido dos Trabalhadores - PT, que, movidos por um urgente chamado no sentido de preencher a lacuna legislativa constante no ordenamento jurídico brasileiro no que se refere ao direito de identidade de gênero, inspiraram-se na célebre lei argentina - a Ley de Identidad de Género - e sua reconhecida consonância com os direitos humanos fundamentais, que foram objeto de estudo ao longo do segundo capítulo deste trabalho.

Conforme fora exposto ao longo dos tópicos anteriores, com exceção do Projeto de Lei n. 5002/2013, que segue pendente de votação pelo Congresso Nacional, o Poder Legislativo brasileiro se absteve de atuar em prol da comunidade dos transgêneros no sentido de garantir o exercício do direito à identidade de gênero. Por esse motivo, temas como acesso às cirurgias de transgenitalização e retificação do registro civil foram, até então, amparados tão somente por portarias, decretos, resoluções e decisões judiciais, inclusive em sede de controle concentrado de constitucionalidade.

A inércia legislativa é reconhecida por órgãos públicos e inúmeras instituições de ensino espalhadas pelo país, que, em uma tentativa de remediar tal inércia e a consequente ausência de lei específica sobre o tema, instituíram a adoção do "nome social". Por meio do "nome social" é concedido ao indivíduo transgênero a possibilidade de determinar a forma como deseja ser identificado perante a sociedade ${ }^{94}$, ferramenta esta que suaviza os prejuízos causados por um Estado que não lhe concede o direito à sua autodeterminação, à sua identidade de gênero e à retificação dos registros civis.

\footnotetext{
${ }^{94}$ BRASÍLIA, Projeto de Lei $\mathrm{n}^{\circ}$ 5002/2013, de fevereiro de 2013. Justificativa, p. 8-9. Disponível em: $<$ http://www.camara.gov.br/proposicoesWeb/prop_mostrarintegra;jsessionid=1072BF74323E8DC005AC D8AC6634149A.proposicoesWebExterno1? codteor $=1059446 \&$ filename $=P L+5002 / 2013>$. Acesso em: 02 jun. 2018.
} 
Apesar de a possibilidade de adoção do "nome social" pelos indivíduos transgêneros se caracterizar como uma grande conquista, nas palavras de Berenice Bento, a adoção do "nome social" significa:

Mudar sem alterar substancialmente nada na vida da população mais excluída da cidadania nacional. Assim, por exemplo, uma estudante transexual terá seu nome feminino na chamada escolar, mas no mercado de trabalho e em todas as outras dimensões da vida terá que continuar se submetendo a todas as situações vexatórias e humilhantes e portar documentos em completa dissonância com suas performances de gênero ${ }^{95}$.

Em que pese a notável importância de todo e qualquer elemento até então analisado, principalmente da ADI n. 4275, para a elevação destes indivíduos ao patamar de efetivos cidadãos, isto é de sujeitos de direitos, a ausência de um diploma legal específico sobre o tema é extremamente prejudicial aos membros dessa comunidade. Afinal, conforme pôde ser verificado no segundo capítulo deste trabalho, no qual foi analisada a Lei n. 26.743/12, com a elaboração e aprovação de diploma legal específico, a tendência é a de que a temática seja abordada de forma muito mais extensiva e pormenorizada, tratando-se não apenas dos direitos instituídos, mas também de todos os critérios procedimentais e dos seus efeitos.

A título exemplificativo, repisa-se que o diploma legal argentino aborda, inclusive, questões relacionadas à obrigação de o próprio Registro Nacional de Pessoas comunicar os demais órgãos estatais acerca da mudança nos assentos civis, à manutenção do número do documento de identidade e dos direitos e obrigações adquiridos pelo sujeito previamente à retificação registral. É certo que qualquer decisão judicial, por mais extensa que possa vir a ser, jamais abordará de forma tão detalhada os aspectos de qualquer relação jurídica.

Ademais, conforme fora abordado ao longo deste capítulo, atualmente, para que o indivíduo transgênero possa ter acesso à cirurgia de transgenitalização no Brasil, é necessário atravessar um período de acompanhamento probatório de, no mínimo, 02 (dois) anos. Ao final desse período probatório, caso não seja

\footnotetext{
95 BENTO, Berenice. Nome social para pessoas trans: cidadania precária e gambiarra legal In: Contemporânea. ISSN: 2236-532X v. 4, n. 1 Jan.-Jun., 2014. p. 9.
} 
emitido laudo médico atestando que o indivíduo possui "disforia de gênero", não será autorizada a realização da referida cirurgia. E, apesar de a decisão da ADI autorizar a retificação registral para aqueles que realizaram, ou não, a cirurgia, esta não dispõe sobre a forma de acesso a mesma.

Diante desta realidade, e com o intuito de legislar em prol dos transgêneros e acerca do direito à retificação registral e às cirurgias transgenitalizadoras, os deputados, em justificativa da proposição do PL n. 5002/2013, pontuam:

O imbróglio jurídico sobre as identidades "legal" e "social" das pessoas travestis, transexuais e transgêneros provoca situações absurdas que mostram o tamanho do furo que ainda existe na legislação brasileira. Graças a ele, há pessoas que vivem sua vida real com um nome - o nome delas, pelo qual são conhecidas e se sentem chamadas, aquele que usam na interação social cotidiana -, mas que carregam consigo um instrumento de identificação legal, uma carteira de identidade, que diz outro nome. E esse nome aparece também na carteira de motorista, na conta de luz, no diploma da escola ou da universidade, na lista de eleitores, no contrato de aluguel, no cartão de crédito, no prontuário médico. Um nome que evidentemente é de outro, daquele "ser imaginário" que habita nos papeis, mas que ninguém conhece no mundo real ${ }^{96}$.

A ausência de lei específica sobre o tema gera uma grande "descontinuidade de existências", visto que aquele indivíduo constante nos registros civis não existe de fato. Enquanto isso, o indivíduo que existe de fato, não consta nos registros civis, fato este que fere veemente o direito à autodeterminação e à identidade de todos aqueles que não se identificam com o gênero e o nome que lhes foram atribuídos tão somente em razão das suas características físicas. Esse cenário, além de impossibilitar/proibir o acesso desses indivíduos ao amplo exercício dos seus direitos fundamentais, contribui de maneira relevante para a proliferação de situações de constrangimento, humilhação e, inclusive, de violência enfrentadas pela população transgênero ${ }^{97}$.

Nesse contexto, ainda que ADI n. 4275, julgada em março de 2018, tenha se caracterizado como um enorme avanço para consecução dos direitos dos indivíduos transgêneros, inúmeros outros aspectos, que, cabe mencionar, são

\footnotetext{
${ }^{96}$ BRASÍLIA, Projeto de Lei no 5002/2013, de fevereiro de 2013. Justificativa, p. 6. Acesso em: 02 jun. 2018.

${ }^{97}$ Trangêneros, transexuais e travestis.
} 
abordados pelo PL de n. 5002/2013, carecem de regulação. Por esse motivo, mostra-se imperiosa a aprovação desse projeto e a sua conversão em lei, garantindo o mais amplo e efetivo acesso a todos os direitos humanos e constitucionais.

\subsubsection{Análise dos Principais Aspectos do PL n. 5002/2013}

Conforme fora mencionado neste trabalho, o Projeto de Lei n. 5002/2013 foi elaborado com base na Lei de Identidade de Gênero da Argentina, sendo certo que, embora corresponda quase à tradução literal deste último, cujas previsões foram devidamente esmiuçadas no capítulo anterior, existem algumas discrepâncias, que serão devidamente abordadas a seguir.

Ademais, a respeito do tema e das similaridades entre o diploma legal argentino e o projeto de lei brasileiro, dispõe Carolina Grant:

O projeto de lei proposto pelo deputado Jean Wyllys, PL 5002/2013, por sua vez,
consiste, basicamente, numa tradução para a língua pátria da lei argentina, com algumas
adaptações para o estilo legislativo brasileiro e para o contexto nacional, como através
da menção ao Sistema Único de Saúde (SUS), no que tange ao acesso gratuito à cirurgia
de redesignação sexual, às intervenções hormonais e à assistência integral à saúde das
pessoas trans (art. $9^{\circ}$ ), bem como mediante a menção ao uso e respeito ao "nome social"
enquanto não for oficializada a alteração do registro civil, na medida em que tem sido
crescente a implementação e o recurso a este instituto enquanto não se aprova um
regramento legal definitivo à questão (art. 10)

O projeto de lei, assim como a Lei de Identidade de Gênero argentina,

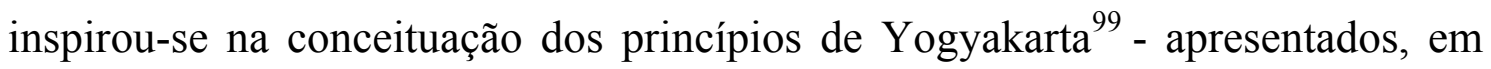
2007, perante a Organização das Nações Unidas - ONU por uma comissão de juristas criada com o intuito de combater as gravíssimas violações aos direitos humanos sofridas pela população LGBT e registradas em todo o mundo.

Em ambos os casos, isto é, no Projeto de Lei brasileiro e na Lei de Identidade de Gênero argentina, a identidade de gênero é definida no artigo $2^{\circ}$ com base na definição constante nos documentos dos princípios de Yogyakarta e

\footnotetext{
${ }^{98}$ GRANT, p. 25 . Acesso em: 15 mai. 2018.

99 Definição sobre identidade de gênero primeiramente expressa no documento dos princípios de Yogyakarta. Acesso em: 21 mai. 2018.
} 
apontada na justificativa do PL n. 5002/3013. Com base nos documentos de Yogyakarta, identidade de gênero é:

\begin{abstract}
A vivência interna e individual do gênero tal como cada pessoa o sente, a qual pode corresponder ou não com o sexo atribuído após o nascimento, incluindo a vivência pessoal do corpo. $\mathrm{O}$ exercício do direito à identidade de gênero pode envolver a modificação da aparência ou da função corporal através de meios farmacológicos, cirúrgicos ou de outra índole, desde que isso seja livremente escolhido. Também inclui outras expressões de gênero, como a vestimenta, os modos e a fala ${ }^{100}$.
\end{abstract}

A definição de identidade de gênero adotada por ambos os instrumentos reafirma a ideia de autodeterminação do indivíduo em relação ao seu corpo, o que, no caso da Lei argentina e do Projeto de Lei brasileiro, traduz-se como pressuposto único para a retificação das informações constantes no registro civil (artigo $4^{\circ}$ ) e para acesso à cirurgia transgenilizadora e/ou tratamento hormonal $\left(\operatorname{artigo} 8^{\circ}\right)$.

A adoção de tal definição combate o determinismo biológico e corrobora os estudos da teoria queer ${ }^{101}$, analisada no primeiro capítulo deste trabalho, garantindo aos transgêneros múltiplas possibilidades de exercer o direito à identidade de gênero, visto que abraça todos aqueles que desejam realizar a cirurgia transgenitalizadora e o tratamento hormonal, assim como aqueles que, apesar de não possuírem esse desejo, pretendem retificar os seus registros civis.

Em consonância com o diploma legal argentino, o PL n. 5002/2013 dissocia o direito à retificação dos registros civis de qualquer tratamento médico, hormonal, psicológico, bem como de qualquer procedimento cirúrgico $\left(\operatorname{art} 4^{\mathrm{o}}\right)^{102}$. $\mathrm{Na}$ mesma linha, confere autonomia ao indivíduo com ao menos 18 (dezoito)

\footnotetext{
${ }^{100}$ BRASÍLIA, Projeto de Lei no 5002/2013, de fevereiro de 2013. Justificativa, p. 10. Acesso em: 02 jun. 2018.

${ }^{101}$ GRANT, p. 21. Acesso em: 15 mai. 2018.

${ }^{102}$ Artigo $4^{\circ}$ - Toda pessoa que solicitar a retificação registral de sexo e a mudança do prenome e da imagem, em virtude da presente lei, deverá observar os seguintes requisitos: I - ser maior de dezoito (18) anos; II - apresentar ao cartório que corresponda uma solicitação escrita, na qual deverá manifestar que, de acordo com a presente lei, requer a retificação registral da certidão de nascimento e a emissão de uma nova carteira de identidade, conservando o número original; III - expressar o/s novo/s prenome/s escolhido/s para que sejam inscritos. Parágrafo único: Em nenhum caso serão requisitos para alteração do prenome: I - intervenção cirúrgica de transexualização total ou parcial; II - terapias hormonais; III qualquer outro tipo de tratamento ou diagnóstico psicológico ou médico; IV - autorização judicial. BRASÍLIA, Projeto de Lei n ${ }^{\circ}$ 5002/2013, de fevereiro de 2013. Art. 4º. Acesso em: 02 jun. 2018.
} 
anos de idade para realizar tratamentos hormonais e se submeter ao procedimento cirúrgico de transgenitalização, sem que, para tanto, seja necessária qualquer sorte de decisão judicial, autorização administrativa, ou, ainda, acompanhamento médico probatório (artigo $\left.8^{\circ}\right)^{103}$.

Assim como no caso do diploma legal argentino, os direitos à retificação registral e de acesso a tratamento médico, hormonal, psicológico, tanto como às cirurgias transgenitalizadoras são extensivos àqueles indivíduos com menos de 18 (dezoito) anos de idade, desde que estes sejam devidamente representados por seus representantes legais. Ademais, ainda que, por qualquer razão, seja negado ou impossível obter o consentimento dos representantes legais, o menor poderá recorrer a Defensoria Pública para autorização judicial (art. $5^{\circ}, \S 1^{\circ}$ e art. $8^{\circ}$, $\left.\S 2^{\circ}\right)^{104}$.

No que se refere aos efeitos decorrentes da retificação registral, o projeto de lei dedica artigo $7^{\circ}$, abaixo transcrito:

Artigo $7^{\circ}$ - A Alteração do prenome, nos termos dos artigos $4^{\circ}$ e $5^{\circ}$ desta Lei, não alterará a titularidade dos direitos e obrigações jurídicas que pudessem corresponder à pessoa com anterioridade à mudança registral, nem daqueles que provenham das

\footnotetext{
${ }^{103}$ Artigo $8^{\circ}$ - Toda pessoa maior de dezoito (18) anos poderá realizar intervenções cirúrgicas totais ou parciais de transexualização, inclusive as de modificação genital, e/ou tratamentos hormonais integrais, a fim de adequar seu corpo à sua identidade de gênero auto-percebida. $\S 1^{\circ}$ Em todos os casos, será requerido apenas o consentimento informado da pessoa adulta e capaz. Não será necessário, em nenhum caso, qualquer tipo de diagnóstico ou tratamento psicológico ou psiquiátrico, ou autorização judicial ou administrativa. $\S 2^{\circ}$ No caso das pessoas que ainda não tenham de dezoito (18) anos de idade, vigorarão os mesmos requisitos estabelecidos no artigo $5^{\circ}$ para a obtenção do consentimento informado.

Artigo $5^{\circ}$ - Com relação às pessoas que ainda não tenham dezoito (18) anos de idade, a solicitação do trâmite a que se refere o artigo $4^{\circ}$ deverá ser efetuada através de seus representantes legais e com a expressa conformidade de vontade da criança ou adolescente, levando em consideração os princípios de capacidade progressiva e interesse superior da criança, de acordo com o Estatuto da Criança e do Adolescente. $\S 1^{\circ}$ Quando, por qualquer razão, seja negado ou não seja possível obter o consentimento de algum/a dos/as representante/s do Adolescente, ele poderá recorrer ele poderá recorrer a assistência da Defensoria Pública para autorização judicial, mediante procedimento sumaríssimo que deve levar em consideração os princípios de capacidade progressiva e interesse superior da criança. Ibid., Art. $8^{\circ}$. Acesso em: 02 jun. 2018.

${ }^{104}$ Artigo $5^{\circ}$ - Com relação às pessoas que ainda não tenham dezoito (18) anos de idade, a solicitação do trâmite a que se refere o artigo $4^{\circ}$ deverá ser efetuada através de seus representantes legais e com a expressa conformidade de vontade da criança ou adolescente, levando em consideração os princípios de capacidade progressiva e interesse superior da criança, de acordo com o Estatuto da Criança e do Adolescente. $\S 1^{\circ}$ Quando, por qualquer razão, seja negado ou não seja possível obter o consentimento de algum/a dos/as representante/s do Adolescente, ele poderá recorrer ele poderá recorrer a assistência da Defensoria Pública para autorização judicial, mediante procedimento sumaríssimo que deve levar em consideração os princípios de capacidade progressiva e interesse superior da criança.

Ibid., Art. 5 . Acesso em: 02 jun. 2018.
} 
relações próprias do direito de família em todas as suas ordens e graus, as que se manterão inalteráveis, incluída a adoção.

$\S 1^{\circ} \mathrm{Da}$ alteração do prenome em cartório prosseguirá, necessariamente, a mudança de prenome e gênero em qualquer outro documento como diplomas, certificados, carteira de identidade, CPF, passaporte, título de eleitor, Carteira Nacional de Habilitação e Carteira de Trabalho e Previdência Social.

$\S 2^{\circ}$ Preservará a maternidade ou paternidade da pessoa trans no registro civil de seus/suas filhos/as, retificando automaticamente também tais registros civis, se assim solicitado, independente da vontade da outra maternidade ou paternidade;

$\S 3^{\circ}$ Preservará o matrimônio da pessoa trans, retificando automaticamente também, se assim solicitado, a certidão de casamento independente de configurar uma união homoafetiva ou heteroafetiva.

$\S 4^{\circ} \mathrm{Em}$ todos os casos, será relevante o número da carteira de identidade e o Cadastro de Pessoa Física da pessoa como garantia de continuidade jurídica ${ }^{105}$.

Como se verifica, assim como no modelo argentino, o artigo dispõe sobre a manutenção do número da carteira de identidade, das obrigações jurídicas e dos direitos anteriores à retificação registral. Neste último ponto - manutenção dos direitos e obrigações-, trata a matéria de forma exaustiva e detalhada, de modo a suprimir toda e qualquer eventual lacuna, garantindo a manutenção dos direitos de família, inclusive, no que tange à maternidade, à paternidade e à preservação do matrimônio.

O diploma brasileiro também aufere gratuidade para que sejam alcançados os direitos pretendidos, reproduzindo aquilo que é perpetuado pelo modelo argentino, ou seja, a garantia de que toda norma, regulamentação ou procedimento deverá respeitar o direito humano à identidade de gênero das $\operatorname{pessoas}^{106}$.

$\mathrm{O}$ artigo $6^{\mathrm{o}}$ do $\mathrm{PL}$ n. 5002/2013, abaixo colacionado, estabelece a necessidade de observação dos princípios da confidencialidade, intimidade e

\footnotetext{
${ }^{105}$ BRASÍLIA, Projeto de Lei n ${ }^{\mathrm{o}}$ 5002/2013, de fevereiro de 2013. Art. $7^{\circ}$. Acesso em: 02 jun. 2018.

${ }^{106}$ Artigo $11^{\circ}$ - Toda norma, regulamentação ou procedimento deverá respeitar o direito humano à identidade de gênero das pessoas. Nenhuma norma, regulamentação ou procedimento poderá limitar, restringir, excluir ou suprimir o exercício do direito à identidade de gênero das pessoas, devendo se interpretar e aplicar as normas sempre em favor do acesso a esse direito.

BRASÍLIA, Projeto de Lei no 5002/2013, de fevereiro de 2013. Art. 11 ${ }^{\circ}$. Acesso em: 02 jun. 2018.
} 
privacidade, sendo certo, contudo, que, nesse aspecto, notam-se algumas discrepâncias em relação ao modelo argentino. Verifica-se a primeira divergência no parágrafo primeiro do art. $6^{\circ}$, in verbis:

Artigo $6^{\circ}$ - Cumpridos os requisitos estabelecidos nos artigos $4^{\circ}$ e $5^{\circ}$, sem necessidade de nenhum trâmite judicial ou administrativo, o/a funcionário/a autorizado do cartório procederá:

I - a registrar no registro civil das pessoas naturais a mudança de sexo e prenome/s;

II - emitir uma nova certidão de nascimento e uma nova carteira de identidade que reflitam a mudança realizada;

III - informar imediatamente os órgãos responsáveis pelos registros públicos para que se realize a atualização de dados eleitorais, de antecedentes criminais e peças judiciais.

$\$ 1^{\circ}$ Nos novos documentos, fica proibida qualquer referência à presente lei ou à identidade anterior, salvo com autorização por escrito da pessoa trans ou intersexual (grifo meu)

$\S 2^{\circ}$ Os trâmites previstos na presente lei serão gratuitos, pessoais, e não será necessária a intermediação de advogados/as ou gestores/as.

$\S 3^{\circ}$ Os trâmites de retificação de sexo e prenome/s realizados em virtude da presente lei serão sigilosos. Após a retificação, só poderão ter acesso à certidão de nascimento original aqueles que contarem com autorização escrita do/a titular da mesma. (grifo meu)

$\S 4^{\circ}$ Não se dará qualquer tipo de publicidade à mudança de sexo e prenome/s, a não ser que isso seja autorizado pelo/a titular dos dados. Não será realizada a publicidade na imprensa que estabelece a lei $6.015 / 73$ (arts. 56 e 57$)^{107}$.

Conforme se afere da leitura do artigo supratranscrito, uma das discrepâncias entre o diploma legal argentino e o projeto de lei brasileiro repousa na previsão constante no parágrafo primeiro, que prevê uma exceção à proibição de anotação nos novos documentos de qualquer menção à retificação registral que venha a ser realizada em atendimento à lei, qual seja: a vontade do próprio requerente. Isso porque, como já fora abordado no segundo capítulo, a lei argentina veda sob qualquer hipótese essa anotação.

${ }^{107}$ BRASÍLIA, Projeto de Lei no 5002/2013, de fevereiro de 2013. Art. $7^{\circ}$. Acesso em: 02 jun. 2018. 
Em relação a esta mudança constante no projeto de lei brasileiro, é possível afirmar que possui um viés positivo, visto que, ao se reconhecer a possibilidade de um indivíduo não se importar com a existência de anotação em seus registros civis, ou, até mesmo, de um indivíduo desejar a realização desta, o PL n. 5002/2013 abraça as mais variadas multiplicidades de identificações generíficas, como, por exemplo, a travestilidade ${ }^{108}$.

No parágrafo terceiro deste mesmo artigo (artigo $6^{\circ}$ ) entre a lei argentina e a brasileira encontra-se uma previsão, por meio qual se estabelece que o acesso ao inteiro teor da certidão de nascimento originária - isto é, anterior à retificação registral - somente será permitido àqueles que possuírem autorização expressa e escrita do titular da mesma. Nota-se, portanto, que foi suprimida a hipótese de acesso ao registro original através de decisão judicial justificada, presente no modelo argentino.

A terceira e última dissonância existente entre ambos os instrumentos corresponde à supressão da previsão acerca da impossibilidade de se retificar novamente os registros civis após a efetivação do primeiro requerimento, exceto mediante autorização judicial, conforme consta no artigo $8^{\circ}$ da Lei de Identidade de Gênero da Argentina.

A segunda e a terceira discrepâncias acima apontadas prejudicam sobremaneira um dos postulados do ordenamento jurídico pátrio, qual seja: a segurança jurídica. Nesse exato sentido, dispõe Carolina Grant:

Tais lacunas do PL 5002/13 - ainda que se tenha expressamente sinalizado para a averbação da mudança do nome (prenome) e sexo do indivíduo no registro civil das pessoas naturais, fazendo constar do Livro do Cartório o registro desta modificação, bem como as informações originais do requerente (art. $6^{\circ}$, I, do PL) - abalam a compatibilização do propósito do projeto, que é o amplo reconhecimento da identidade de gênero das pessoas trans, com o postulado basilar do ordenamento jurídico pátrio, a segurança jurídica. Isso porque a ausência da norma restritiva às alterações abre espaço para a facilidade e a frequência destas, o que pode, ainda que não deva, estimular o mal uso (ou abuso) da lei ${ }^{109}$.

\footnotetext{
108 SILVA, 2016, p. 13.

${ }^{109}$ GRANT, p. 27 . Acesso em: 15 mai. 2018.
} 
Ao longo do seu estudo, Grant dispõe, ainda, que caso o projeto de lei brasileiro correspondesse à exata tradução do diploma legal argentino e, por consequência, se não possuísse as referidas lacunas, os direitos da personalidade dos indivíduos transgêneros permaneceriam preservados e o PL n. 5002/2013 não viria a representar qualquer ameaça à manutenção da segurança jurídica do ordenamento brasileiro, fato este que, por certo, contribuiria para diminuir as críticas sofridas e para a sua efetiva aprovação.

Por fim, o projeto de lei dispõe acerca da modificação da redação do artigo 58 da Lei 6.015/ 73 - Lei de Registros Públicos -, que passaria a viger conforme indicado abaixo, bem como sobre a revogação de toda norma contrária às suas disposições:

Art. $58^{\circ}$. O prenome será definitivo, exceto nos casos de discordância com a identidade de gênero auto-percebida, para os quais se aplicará a lei de identidade de gênero. Admite-se também a substituição do prenome por apelidos públicos notórios ${ }^{110}$.

Diante de todo o acima exposto, verifica-se que o Projeto de Lei n. 5002/2013, assim como o modelo argentino (Lei n. 26.743/2013), dispõe sobre o direito à identidade de gênero, em razão do qual propõe a alteração da redação do artigo 58 da Lei de Registros Públicos e possibilita a retificação dos registros civis sem a necessidade de decisão judicial e/ou administrativa, bem como de qualquer sorte de tratamento médico (hormonal ou cirurgia), possuindo seu objeto grande similaridade com o da ADI 4275.

Contudo, é certo que, em razão do tratamento detalhado conferido à matéria, mesmo diante do recente julgamento da referida ADI em março desse ano e da existência de algumas lacunas que possivelmente, no caso de aprovação deste projeto, venham a causar prejuízos à segurança jurídica do ordenamento jurídico brasileiro, a conversão do PL n. 5002/2013 em lei pelo Congresso Nacional se faz importantíssima para que, finalmente, os indivíduos transgêneros sejam elevados ao patamar de sujeitos de direito, principalmente ao direito de autodeterminação.

\footnotetext{
${ }^{110}$ Artigo $13^{\circ}$ - Revoga-se toda norma que seja contrária às disposições da presente lei. BRASÍLIA, Projeto de Lei no 5002/2013, de fevereiro de 2013. Art. 13º. Acesso em: 02 jun. 2018.
} 
Por fim, de modo a melhor ilustrar as similaridades e divergências entre o Projeto de Lei e a Lei Argentina, também foi elaborada a tabela comparativa abaixo colacionada:

\begin{tabular}{|c|c|}
\hline PL n. 5002/2013 & Lei Argentina 26.743/2012 \\
\hline \multicolumn{2}{|c|}{ Artigo $1^{\circ}$} \\
\hline $\begin{array}{l}\text { Artigo } 1^{\circ} \text { - Toda pessoa tem direito: } \\
\text { I - ao reconhecimento de sua } \\
\text { identidade de gênero; } \\
\text { II - ao livre desenvolvimento de sua } \\
\text { pessoa conforme sua identidade de } \\
\text { gênero; } \\
\text { III - a ser tratada de acordo com sua } \\
\text { identidade de gênero e, em particular, } \\
\text { a ser identificada dessa maneira nos } \\
\text { instrumentos que acreditem sua } \\
\text { identidade pessoal a respeito do/s } \\
\text { prenome/s, da imagem e do sexo com } \\
\text { que é registrada neles. }\end{array}$ & $\begin{array}{l}\text { ARTICULO } 1^{\circ}-\text { Derecho a la } \\
\text { identidad de género. Toda persona } \\
\text { tiene derecho: } \\
\text { a) Al reconocimiento de su identidad } \\
\text { de género; } \\
\text { b) Al libre desarrollo de su persona } \\
\text { conforme a su identidad de género; } \\
\text { c) A ser tratada de acuerdo con su } \\
\text { identidad de género y, en particular, a } \\
\text { ser identificada de ese modo en los } \\
\text { instrumentos que acreditan su } \\
\text { identidad respecto de el/los nombre/s } \\
\text { de pila, imagen y sexo con los que allí } \\
\text { es registrada }\end{array}$ \\
\hline \multicolumn{2}{|c|}{$\begin{array}{l}\text { Comentário: Verifica-se que o artigo } 1^{\circ} \text { do PL n. } 5002 / 2013 \text { corresponde à } \\
\text { tradução literal do artigo } 1^{\circ} \text { da Lei Argentina } 26.743 / 2012\end{array}$} \\
\hline \multicolumn{2}{|c|}{ Artigo $2^{\circ}$} \\
\hline $\begin{array}{l}\text { Artigo } 2^{\circ} \text { - Entende-se por identidade } \\
\text { de gênero a vivência interna e }\end{array}$ & $\begin{array}{l}\text { ARTICULO } 2^{\circ}-\text { Definición. Se } \\
\text { entiende por identidad de género a la }\end{array}$ \\
\hline
\end{tabular}




\begin{tabular}{|c|c|}
\hline $\begin{array}{l}\text { individual do gênero tal como cada } \\
\text { pessoa o sente, a qual pode } \\
\text { corresponder ou não com o sexo } \\
\text { atribuído após o nascimento, } \\
\text { incluindo a vivência pessoal do corpo. } \\
\text { Parágrafo único: O exercício do } \\
\text { direito à identidade de gênero pode } \\
\text { envolver a modificação da aparência } \\
\text { ou da função corporal através de } \\
\text { meios farmacológicos, cirúrgicos ou } \\
\text { de outra índole, desde que isso seja } \\
\text { livremente escolhido, e outras } \\
\text { expressões de gênero, inclusive } \\
\text { vestimenta, modo de fala e } \\
\text { maneirismos. }\end{array}$ & $\begin{array}{l}\text { vivencia interna e individual del } \\
\text { género tal como cada persona la } \\
\text { siente, la cual puede corresponder o } \\
\text { no con el sexo asignado al momento } \\
\text { del nacimiento, incluyendo la vivencia } \\
\text { personal del cuerpo. Esto puede } \\
\text { involucrar la modificación de la } \\
\text { apariencia o la función corporal a } \\
\text { través de medios farmacológicos, } \\
\text { quirúrgicos o de otra indole, siempre } \\
\text { que ello sea libremente escogido. } \\
\text { También incluye otras expresiones de } \\
\text { género, como la vestimenta, el modo } \\
\text { de hablar y los modales. }\end{array}$ \\
\hline \multicolumn{2}{|c|}{$\begin{array}{l}\text { Comentário: Verifica-se que o artigo } 2^{\circ} \text { do PL n. 5002/2013 corresponde à } \\
\text { tradução literal do artigo } 2^{\circ} \text { da Lei Argentina } 26.743 / 2012\end{array}$} \\
\hline \multicolumn{2}{|c|}{ Artigo $3^{\circ}$} \\
\hline $\begin{array}{l}\text { Artigo } 3^{0}-\text { Toda pessoa poderá } \\
\text { solicitar a retificação registral de sexo } \\
\text { e a mudança do prenome e da imagem } \\
\text { registradas na documentação pessoal, } \\
\text { sempre que não coincidam com a sua } \\
\text { identidade de gênero auto-percebida. }\end{array}$ & $\begin{array}{l}\text { ARTICULO } 3^{\circ}-\text { Ejercicio. Toda } \\
\text { persona podrá solicitar la } \\
\text { rectificación registral del sexo, y el } \\
\text { cambio de nombre de pila e imagen, } \\
\text { cuando no coincidan con su identidad } \\
\text { de género autopercibida. }\end{array}$ \\
\hline \multicolumn{2}{|c|}{$\begin{array}{l}\text { Comentário: Verifica-se que o artigo } 3^{\circ} \text { do PL n. 5002/2013 corresponde à } \\
\text { tradução literal do artigo } 3^{\circ} \text { da Lei Argentina } 26.743 / 2012 \text {. }\end{array}$} \\
\hline & \\
\hline
\end{tabular}


Artigo $4^{\circ}$ - Toda pessoa que solicitar a retificação registral de sexo e a mudança do prenome e da imagem, em virtude da presente lei, deverá observar os seguintes requisitos:

I - ser maior de dezoito (18) anos;

II - apresentar ao cartório que corresponda uma solicitação escrita, na qual deverá manifestar que, de acordo com a presente lei, requer a retificação registral da certidão de nascimento e a emissão de uma nova carteira de identidade, conservando o número original;

III - expressar o/s novo/s prenome/s escolhido/s para que sejam inscritos.

Parágrafo único: Em nenhum caso serão requisitos para alteração do prenome:

I - intervenção cirúrgica de transexualização total ou parcial;
ARTICULO $4^{o}-$ Requisitos. Toda persona que solicite la rectificación registral del sexo, el cambio de nombre de pila e imagen, en virtud de la presente ley, deberá observar los siguientes requisitos:

1. Acreditar la edad mínima de dieciocho (18) años de edad, con excepción de lo establecido en el artículo $5^{\circ}$ de la presente ley.

2. Presentar ante el Registro Nacional de las Personas o sus oficinas seccionales correspondientes, una solicitud manifestando encontrarse amparada por la presente ley, requiriendo la rectificación registral de la partida de nacimiento y el nuevo documento nacional de identidad correspondiente, conservándose el número original.

3. Expresar el nuevo nombre de pila elegido con el que solicita inscribirse.

En ningún caso será requisito acreditar intervención quirúrgica por reasignación genital total o parcial, ni acreditar terapias hormonales $u$ otro tratamiento psicológico o médico. 


II - terapias hormonais;
III - qualquer outro tipo de tratamento
ou diagnóstico psicológico ou médico;
IV - autorização judicial.

Comentário: Verifica-se que o artigo $4^{\circ}$ do PL n. 5002/2013 possui grande similaridade artigo $4^{\circ}$ da Lei Argentina 26.743/2012. Diferentemente do PL brasileiro (art. $4^{\mathrm{o}}$, p. ú, IV), o artigo $4^{\circ}$ da Lei Argentina não enumera autorização judicial como um dos elementos desnecessários para a alteração do prenome, sendo certo, contudo, que a Lei Argentina dispõe nesse sentido em seus artigos $6^{\circ}$ e $8^{\circ}$.

\section{Artigo 50}

Artigo $5^{\circ}$ - Com relação às pessoas que ainda não tenham dezoito (18) anos de idade, a solicitação do trâmite a que se refere o artigo $4^{\circ}$ deverá ser efetuada através de seus representantes legais e com a expressa conformidade de vontade da criança ou adolescente, levando em consideração os princípios de capacidade progressiva e interesse superior da criança, de acordo com o Estatuto da Criança e do Adolescente.
ARTICULO $5^{\circ}$ - Personas menores de edad. Con relación a las personas menores de dieciocho (18) años de edad la solicitud del trámite a que refiere el artículo $4^{\circ}$ deberá ser efectuada a través de sus representantes legales y con expresa conformidad del menor, teniendo en cuenta los principios de capacidad progresiva e interés superior del niño/a de acuerdo con lo estipulado en la Convención sobre los Derechos del Niño y en la Ley 26.061 de protección integral de los derechos de niñas, niños y adolescentes. Asimismo, la persona menor de edad deberá contar con la asistencia del abogado del niño prevista en el 


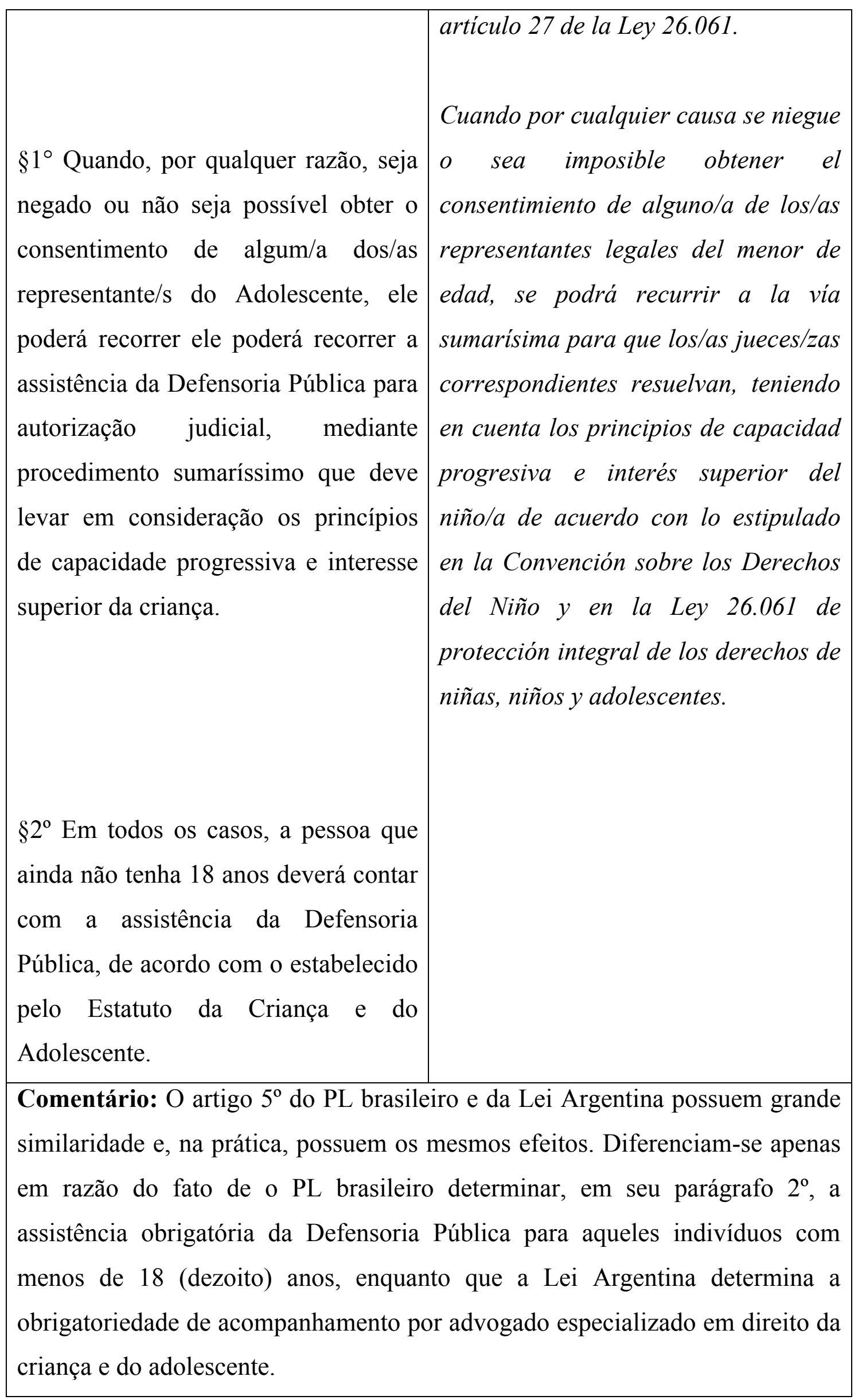




\begin{tabular}{|c|c|}
\hline \multicolumn{2}{|c|}{ Artigo $6^{\circ}$} \\
\hline $\begin{array}{l}\text { Artigo } 6^{\circ} \text { - Cumpridos os requisitos } \\
\text { estabelecidos nos artigos } 4^{\circ} \text { e } 5^{\circ} \text {, sem } \\
\text { necessidade de nenhum trâmite } \\
\text { judicial ou administrativo, o/a } \\
\text { funcionário/a autorizado do cartório } \\
\text { procederá: } \\
\text { I - a registrar no registro civil das } \\
\text { pessoas naturais a mudança de sexo e } \\
\text { prenome/s; } \\
\text { II - emitir uma nova certidão de } \\
\text { nascimento e uma nova carteira de } \\
\text { identidade que reflitam a mudança } \\
\text { realizada; } \\
\text { III - informar imediatamente os } \\
\text { órgãos responsáveis pelos registros } \\
\text { públicos para que se realize a } \\
\text { atualização de dados eleitorais, de } \\
\text { antecedentes criminais e peças } \\
\text { judiciais. }\end{array}$ & $\begin{array}{l}\text { ARTICULO } 6^{\circ} \text { - Trámite. Cumplidos } \\
\text { los requisitos establecidos en los } \\
\text { artículos } 4^{\circ} \text { y } 5^{\circ} \text {, el/la oficial público } \\
\text { procederá, sin necesidad de ningún } \\
\text { trámite judicial o administrativo, a } \\
\text { notificar de oficio la rectificación de } \\
\text { sexo y cambio de nombre de pila al } \\
\text { Registro Civil de la jurisdicción } \\
\text { donde fue asentada el acta de } \\
\text { nacimiento para que proceda a emitir } \\
\text { una nueva partida de nacimiento } \\
\text { ajustándola a dichos cambios, y a } \\
\text { expedirle un nuevo documento } \\
\text { nacional de identidad que refleje la } \\
\text { rectificación registral del sexo y el } \\
\text { nuevo nombre de pila. Se prohibe } \\
\text { cualquier referencia a la presente ley } \\
\text { en la partida de nacimiento } \\
\text { rectificada y en el documento } \\
\text { virtud de la misma. }\end{array}$ \\
\hline $\begin{array}{l}\S 1^{\circ} \text { Nos novos documentos, fica } \\
\text { proibida qualquer referência à } \\
\text { presente lei ou à identidade anterior, } \\
\text { salvo com autorização por escrito da } \\
\text { pessoa trans ou intersexual. }\end{array}$ & $\begin{array}{l}\text { Los trámites para la rectificación } \\
\text { registral previstos en la presente ley } \\
\text { son gratuitos, personales y no será } \\
\text { necesaria la intermediación de ningún } \\
\text { gestor o abogado. }\end{array}$ \\
\hline
\end{tabular}


$\S 2^{\circ}$ Os trâmites previstos na presente lei serão gratuitos, pessoais, e não será necessária a intermediação de advogados/as ou gestores/as.

$\S 3^{\circ}$ Os trâmites de retificação de sexo e prenome/s realizados em virtude da presente lei serão sigilosos. Após a retificação, só poderão ter acesso à certidão de nascimento original aqueles que contarem com autorização escrita do/a titular da mesma.

$\S^{\circ}$ Não se dará qualquer tipo de publicidade à mudança de sexo e prenome/s, a não ser que isso seja autorizado pelo/a titular dos dados. Não será realizada a publicidade na imprensa que estabelece a lei 6.015/73 (arts. 56 e 57).

Comentário: Conforme se verifica a partir da leitura dos artigos $6^{\circ}$ supra colacionados, o PL brasileiro diferencia-se nos seguintes pontos: (i) autoriza a inclusão de referência à lei ou à identidade anterior nos documentos de identidade, caso o indivíduo transgênero autorize, sendo certo que, na Lei Argentina, a referência é proibida em qualquer hipótese; e (ii) determina que, após a retificação, só poderão ter acesso à certidão de nascimento original aqueles que contarem com autorização escrita do titular, enquanto que a Lei Argentina também estipula a possibilidade de a certidão ser acessada por meio de decisão judicial motivada (artigo $9^{\circ}$, caput, da Lei Argentina). 
O parágrafo $4^{\circ}$ do artigo $6^{\circ}$ do PL n. 5002/2013 corresponde ao artigo $9^{\circ}$ da Lei Argentina.

\section{Artigo $7^{\circ}$}

Artigo $7^{\circ}$ - A Alteração do prenome, ARTICULO $7^{\circ}$ - Efectos. Los efectos nos termos dos artigos $4^{\circ}$ e $5^{\circ}$ desta de la rectificación del sexo y el/los Lei, não alterará a titularidade dos nombre/s de pila, realizados en virtud direitos e obrigações jurídicas que de la presente ley serán oponibles a pudessem corresponder à pessoa com terceros desde el momento de su anterioridade à mudança registral, inscripción en el/los registro/s.

nem daqueles que provenham das relações próprias do direito de família em todas as suas ordens e graus, as que se manterão inalteráveis, incluída a adoção.

$\S 1^{\circ}$ Da alteração do prenome em La rectificación registral no alterará la titularidad de los derechos y obligaciones jurídicas que pudieran corresponder a la persona con anterioridad a la inscripción del cambio registral, ni las provenientes cartório prosseguirá, necessariamente, a mudança de prenome e gênero em qualquer outro documento como diplomas, certificados, carteira de identidade, $\mathrm{CPF}$, passaporte, título de eleitor, Carteira Nacional de Habilitação e Carteira de Trabalho e Previdência Social.

$\S 2^{\circ}$ Preservará a maternidade ou de las relaciones propias del derecho de familia en todos sus órdenes y grados, las que se mantendrán inmodificables, incluida la adopción.

En todos los casos será relevante el número de documento nacional de identidad de la persona, por sobre el nombre de pila o apariencia paternidade da pessoa trans no registro civil de seus/suas filhos/as, 


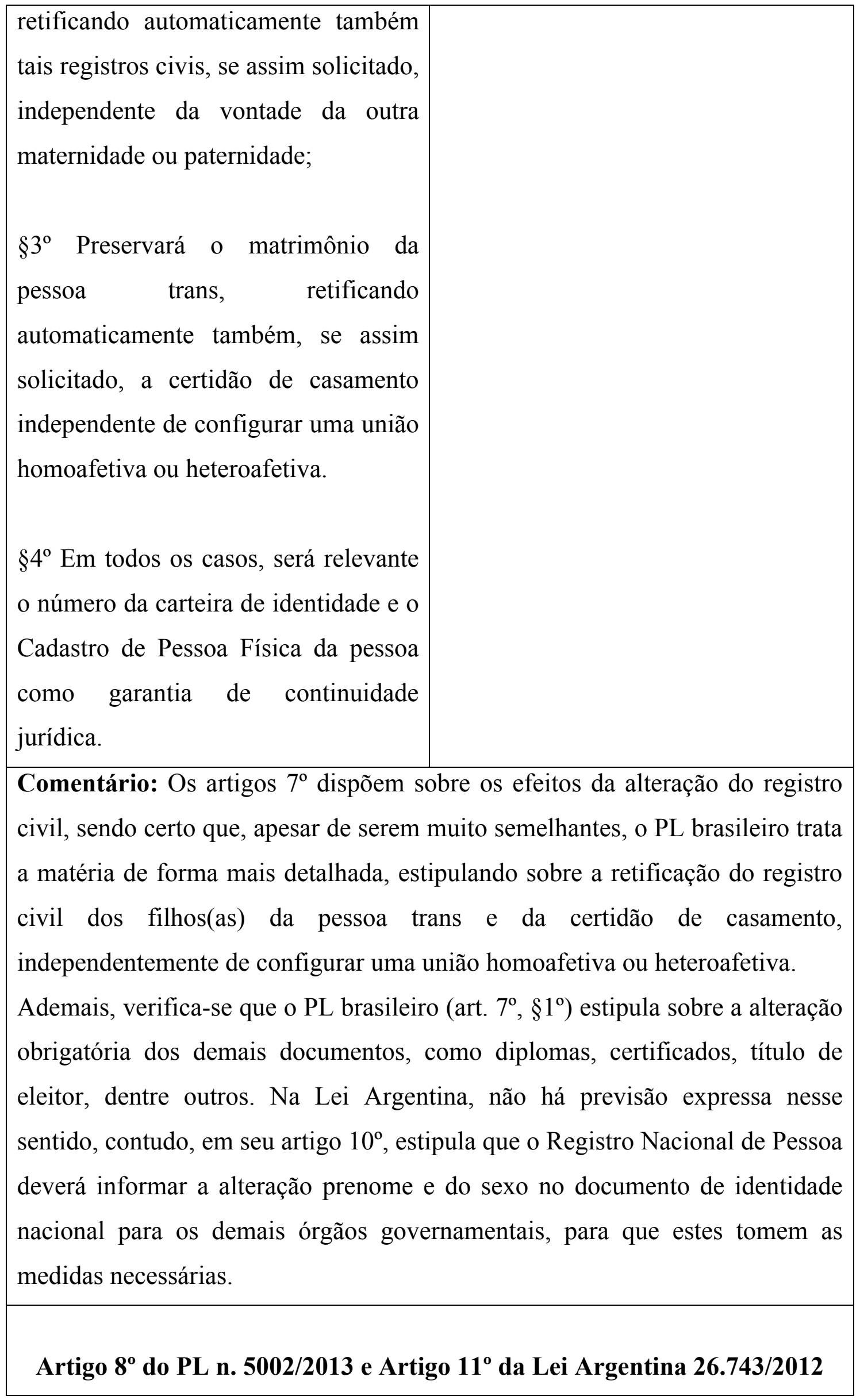


Artigo $8^{\circ}$ - Toda pessoa maior de dezoito (18) anos poderá realizar intervenções cirúrgicas totais ou parciais de transexualização, inclusive as de modificação genital, e/ou tratamentos hormonais integrais, a fim de adequar seu corpo à sua identidade de gênero auto-percebida.

$\S 1^{\circ}$ Em todos os casos, será requerido apenas o consentimento informado da pessoa adulta e capaz. Não será necessário, em nenhum caso, qualquer tipo de diagnóstico ou tratamento psicológico ou psiquiátrico, ou autorização judicial ou administrativa.

$\S 2^{\circ}$ No caso das pessoas que ainda não tenham de dezoito (18) anos de idade, vigorarão os mesmos requisitos estabelecidos no artigo $5^{\circ}$ para a obtenção do consentimento informado.
ARTICULO 11. - Derecho al libre desarrollo personal. Todas las personas mayores de dieciocho (18) años de edad podrán, conforme al artículo $1^{\circ}$ de la presente ley y a fin de garantizar el goce de su salud integral, acceder a intervenciones quirúrgicas totales y parciales y/o tratamientos integrales hormonales para adecuar su cuerpo, incluida su genitalidad, a su identidad de género autopercibida, sin necesidad de requerir autorización judicial o administrativa.

Para el acceso a los tratamientos integrales hormonales, no será necesario acreditar la voluntad en la intervención quirúrgica de reasignación genital total o parcial. En ambos casos se requerirá, únicamente, el consentimiento informado de la persona. En el caso de las personas menores de edad regirán los principios y requisitos establecidos en el artículo $5^{\circ}$ para la obtención del consentimiento informado. Sin perjuicio de ello, para el caso de la obtención del mismo respecto de la intervención quirúrgica 


\begin{tabular}{|l|l|}
\hline e da Lei Argentina. Nota-se, contudo, que a Lei Argentina estabelece a \\
además, con la conformidad de la \\
autoridad judicial competente de cada \\
jurisdicción, quien deberá velar por \\
los principios de capacidad \\
progresiva e interés superior del niño \\
o niña de acuerdo con lo estipulado \\
por la Convención sobre los Derechos \\
del Niño y en la Ley 26.061 de \\
protección integral de los derechos de \\
las niñas, niños y adolescentes. La \\
autoridad judicial deberá expedirse \\
en un plazo no mayor de sesenta (60) \\
días contados a partir de la solicitud \\
de conformidad. \\
Los efectores del sistema público de \\
salud, ya sean estatales, privados o \\
del subsistema de obras sociales, \\
deberán garantizar en forma \\
permanente los derechos que esta ley \\
reconoce. \\
Todas las prestaciones de salud \\
contempladas en el presente artículo \\
quedan incluidas en el Plan Médico \\
Obligatorio, o el que lo reemplace, \\
conforme lo reglamente la autoridad \\
de aplicación.
\end{tabular}




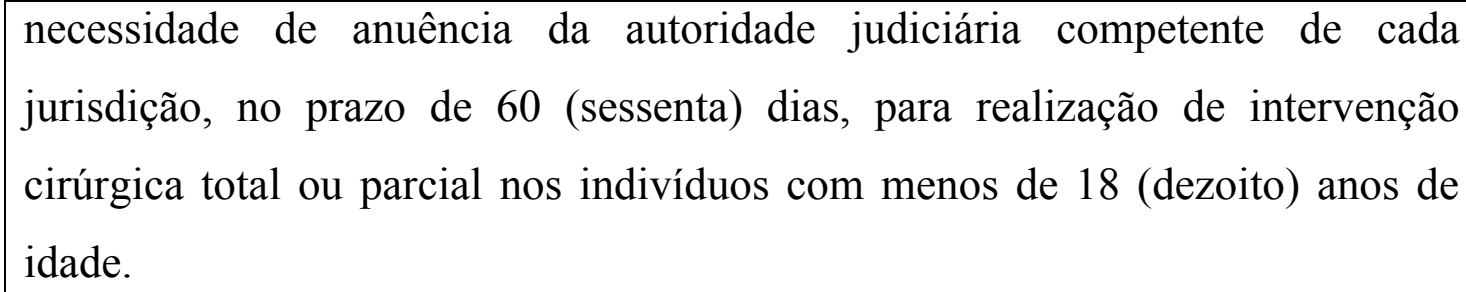
jurisdição, no prazo de 60 (sessenta) dias, para realização de intervenção cirúrgica total ou parcial nos indivíduos com menos de 18 (dezoito) anos de idade.

\section{Artigo 90}

Artigo $9^{\circ}$ - Os tratamentos referidos no artigo $11^{\circ}$ serão gratuitos e deverão ser oferecidos pelo Sistema Único de Saúde (SUS) e pelas operadoras definidas nos incisos I e II do $\S 1^{\circ}$ do art. $1^{\circ}$ da Lei $9.656 / 98$, por meio de sua rede de unidades conveniadas.

Parágrafo único: É vedada a exclusão de cobertura ou a determinação de requisitos distintos daqueles especificados na presente lei para a realização dos mesmos.

Comentário: $\mathrm{O}$ artigo $9^{\circ}$ do PL brasileiro correlaciona-se com trecho do artigo $11^{\circ}$ da Lei Argentina, supratranscrito. No caso argentino, determina-se a obrigatoriedade de todo o sistema de saúde - público e particular - observar o estipulado pela Lei, bem como a inclusão no Plano Médico Obrigatório de todos os serviços de saúde necessários.

Artigo $10^{\circ}$ do PL n. 5002/2013 e Artigo $12^{\circ}$ da Lei Argentina 26.743/2012

Artigo $10^{\circ}$ - Deverá ser respeitada a ARTICULO 12 - Trato digno. identidade de gênero adotada pelas Deberá respetarse la identidad de pessoas que usem um prenome género adoptada por las personas, en 


\begin{tabular}{|c|c|}
\hline $\begin{array}{l}\text { distinto daquele que figura na sua } \\
\text { carteira de identidade e ainda não } \\
\text { tenham realizado a retificação } \\
\text { registral. } \\
\text { Parágrafo único: O nome social } \\
\text { requerido deverá ser usado para a } \\
\text { citação, chamadas e demais interações } \\
\text { verbais ou registros em âmbitos } \\
\text { públicos ou privados. }\end{array}$ & 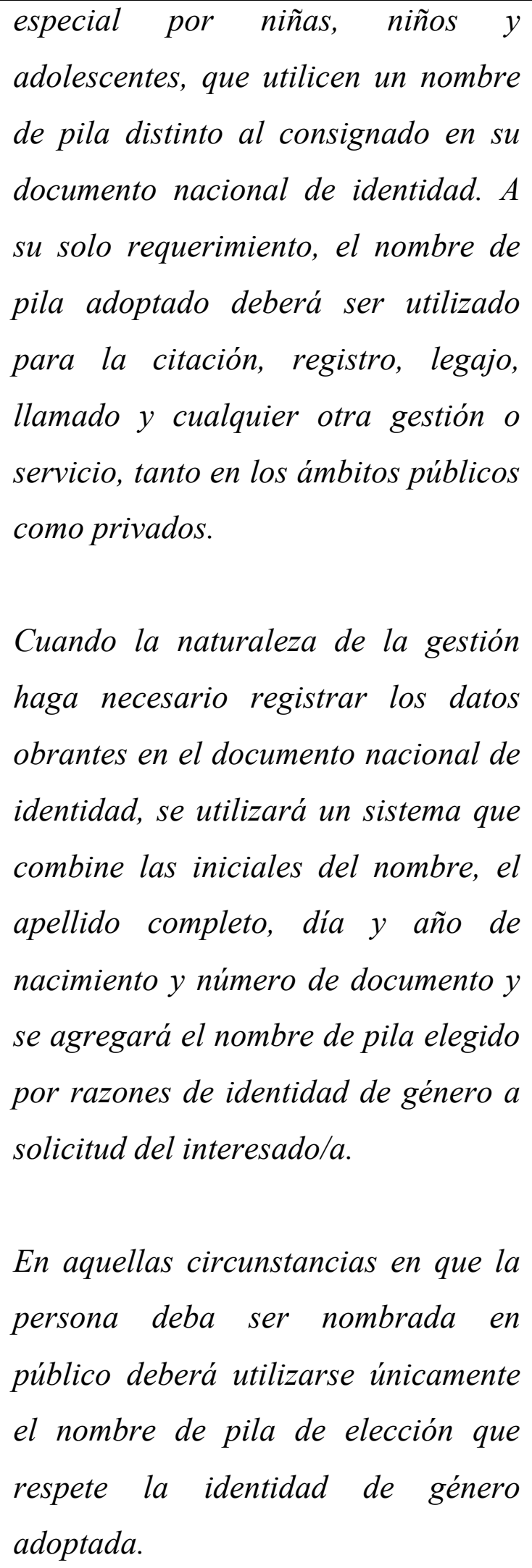 \\
\hline \multicolumn{2}{|c|}{$\begin{array}{l}\text { Comentário: Verifica-se que o artigo } 10^{\circ} \text { do PL brasileiro e o artigo } 12^{\circ} \text { da Lei } \\
\text { Argentina possuem grande similaridade, apesar de a Lei Argentina tratar sobre } \\
\text { a matéria de forma mais extensa. }\end{array}$} \\
\hline
\end{tabular}




\section{Artigo $11^{\circ}$ do PL n. 5002/2013 e Artigo $13^{\circ}$ da Lei Argentina 26.743/2012}

\begin{tabular}{|c|c|}
\hline $\begin{array}{l}\text { Artigo } 11^{\circ}-\text { Toda norma, } \\
\text { regulamentação ou procedimento } \\
\text { deverá respeitar o direito humano à } \\
\text { identidade de gênero das pessoas. } \\
\text { Nenhuma norma, regulamentação ou } \\
\text { procedimento poderá limitar, } \\
\text { restringir, excluir ou suprimir o } \\
\text { exercício do direito à identidade de } \\
\text { gênero das pessoas, devendo se } \\
\text { interpretar e aplicar as normas sempre } \\
\text { em favor do acesso a esse direito. }\end{array}$ & $\begin{array}{l}\text { ARTICULO } 13 .- \text { Aplicación. Toda } \\
\text { norma, reglamentación } \\
\text { procedimiento deberá respetar el } \\
\text { derecho humano a la identidad de } \\
\text { género de las personas. Ninguna } \\
\text { norma, reglamentación } \\
\text { procedimiento podrá limitar, } \\
\text { restringir, excluir o suprimir el } \\
\text { ejercicio del derecho a la identidad de } \\
\text { género de las personas, debiendo } \\
\text { interpretarse y aplicarse las normas } \\
\text { siempre a favor del acceso al mismo. }\end{array}$ \\
\hline
\end{tabular}

Comentário: Verifica-se que o artigo $11^{\circ}$ do PL n. 5002/2013 corresponde à tradução literal do artigo $13^{\circ}$ da Lei Argentina 26.743/2012

\section{Artigo 120}

Artigo $12^{\circ}$ - Modifica-se o artigo $58^{\circ}$ da lei 6.015/73, que ficará redigido da seguinte forma:

"Art. 58 . O prenome será definitivo, exceto nos casos de discordância com a identidade de gênero auto-percebida, para os quais se aplicará a lei de identidade de gênero. Admite-se também a substituição do prenome por apelidos públicos notórios." 
Comentário: $\mathrm{O}$ artigo $12^{\circ}$ do PL n. 5002/2013 propõe a alteração do artigo 58 da Lei de Registros Públicos, de modo a que este passe a autorizar a alteração do prenome para os indivíduos transgêneros. Na forma do artigo 14 da Lei Argentina, revoga-se apenas o inciso quarto, do artigo 19 da Lei 17.132, que proibia a realização de intervenções cirúrgicas que modificassem o sexo do enfermo, exceto mediante autorização judicial.

Logo, não há artigo correspondente na Lei Argentina n. 26.743/2012.

\section{Artigo $1^{\circ}$}

Artigo $13^{\circ}$ - Revoga-se toda norma que seja contrária às disposições da presente lei.

Comentário: Conforme mencionado acima, a Lei Argentina revoga (ao menos de forma expressa) tão somente o artigo 19, inciso quarto, da Lei n. 17.132.

\section{Artigo $14^{\circ}$}

Artigo $14^{\circ}$ - A presente lei entra em vigor na data de sua publicação

Comentário: Não há artigo correspondente na Lei n. 26.743/2012. 


\section{CONCLUSÃO}

Conclui-se o presente trabalho após extensa análise inicial do movimento feminista no mundo, principalmente das teorias gênero de autoras pertencentes ao feminismo pós-estruturalista, como Judith Butler e Joan Scott, e da consequente construção do conceito de identidade de gênero como característica dissociada da sexualidade, resultante do entendimento de gênero como resultado de uma construção social, e não proveniente de um determinismo natural.

A análise acima mencionada, constante no primeiro capítulo deste trabalho, foi seguida pelo estudo, no segundo e terceiro capítulos, do tratamento concedido pelo ordenamento jurídico brasileiro e argentino aos indivíduos transgêneros, no que se refere ao direito de autoderminação, traduzido na possibilidade (ou na ausência) de acesso à cirurgia transgenitalizadora, ao tratamento hormonal e, ainda, no direito de retificação registral, sem que, para tanto, seja necessário qualquer tipo de decisão judicial, autorização administrativa e/ou acompanhamento médico probatório.

Conforme se verificou, para o Conselho Federal de Medicina do Brasil e para a OMS, a transexualidade ainda é enquadrada como uma condição patológica (CID-10, F64.0 - "transexualismo"), e, para que o indivíduo transgênero possa ter acesso à cirurgia transgenitalizadora é necessário o acompanhamento médico probatório por equipe multidisciplinar por, ao menos, 02 (dois anos). Ademais, como fora destacado, ainda é possível que, ao final desse período, a equipe médica entenda que o indivíduo não está apto a realizar tal procedimento.

Nesse sentido, apesar de relevantes avanços para a comunidade transgênero no decorrer dos últimos anos, principalmente com a decisão de procedência do mérito da ADI 4275 em março de 2018, e da promessa de um futuro promissor, no qual essa "condição" poderá ser despatologizada pela OMS na CID-11, no Brasil, o tratamento legislativo sobre a questão trans ainda se 
mostra incipiente, motivo pelo qual não há qualquer garantia para que esses indivíduos exerçam de forma plena o seu direito a autodeterminação de gênero.

Por esse motivo, apesar de ser possível endereçar críticas ao Projeto de Lei n. 5002/2013, no que tange, principalmente, a eventuais prejuízos à segurança jurídica do ordenamento jurídico pátrio, diante da latente necessidade de se assegurar a esses indivíduos o direito de existir em conformidade com sua auto percepção de existência, demonstra-se inquestionável a necessidade de conversão desse projeto em Lei Federal.

Afinal, conforme asseveram os Deputados Federais Jean Wyllys e Érika Kokay na justificativa do referido Projeto Lei:

Quem determina quem tem direito a ser João ou Maria? O que é um nome? (...) Não há como o Estado determinar por lei a autencidade masculina dos homens ou a autêntica feminidade das mulheres! (...) só é homem ou mulher quem se garante ${ }^{111}$.

${ }^{111}$ BRASÍLIA, Projeto de Lei $\mathrm{n}^{\mathrm{0}}$ 5002/2013, de fevereiro de 2013. Justificativa, p. 8. Acesso em: 02 jun. 2018. 


\section{REFERÊNCIAS BIBLIOGRÁFICAS}

ARGENTINA. Frente Nacional por la Ley de Identidad de Género (FNLIG). Projeto n. 8.126_D-2010. Disponível em:

$<$ http://frentenacionaleydeidentidad.blogspot.com.ar $>$. Acesso em: 15 mai. 2018.

ARGENTINA. Ley n. 26.618, de 15 de julho de 2010. Promulgada em 21 de julho de 2010. Código Civil. Modificación. Boletín Oficial de la República Argentina, Buenos Aires, 21 jul. 2010. Disponível em:

$<$ http://servicios.infoleg.gob.ar/infolegInternet/anexos/165000169999/169608/norma.htm>. Acesso em: 15 mai. 2018.

ARGENTINA. Ley n. 26.743 de mayo de 2012. Disponível em: $<$ http://servicios.infoleg.gob.ar/infolegInternet/anexos/195000199999/197860/norma.htm> Acesso em: 13 mai. 2018.

BARCELlOS, Ana Paula. p. 181-182. Normatividade dos Princípiios e o Princípio da Dignidade da Pessoa Humana na Constituição de 1988. Disponível em: <file:///Users/administrator/Downloads/47588-93204-1PB.pdf $>$. Acesso em: 02 jun. 2018.

BENTO, Berenice. Nome social para pessoas trans: cidadania precária e gambiarra legal In: Contemporânea. ISSN: 2236-532X v. 4, n. 1 Jan.-Jun., 2014.

BENTO, Berenice. O que é transexualidade. São Paulo: Brasiliense, 2008.

BRASIL. Lei nº 6.015, de 31 de dezembro de 1973. Disponível em: $<$ http://www.planalto.gov.br/ccivil_03/Leis/L6015original.htm>. Acesso em: 02 jun. 2018.

BRASIL. Ministério da Saúde. Portaria n. 2.803/2013. Disponível em: $<$ http://bvsms.saude.gov.br/bvs/saudelegis/gm/2013/prt2803_19_11_2013.h tml>. Acesso em: 16 mai. 2018.

BRASÍLIA, Projeto de Lei n ${ }^{\circ}$ 5002/2013, de fevereiro de 2013. Disponível em:

$<$ http://www.camara.gov.br/proposicoesWeb/prop_mostrarintegra;jsessioni 
$\mathrm{d}=$ 1072BF74323E8DC005ACD8AC6634149A.proposicoesWebExterno1?c odteor $=1059446 \&$ filename $=P L+5002 / 2013>$. Acesso em: 02 jun. 2018.

BUTLER, Judith. Problemas de Gênero: Feminismo e subversão da identidade. Rio de Janeiro: Editora Civilização Brasileira, 2013.

CARTA CAPITAL. Fila para cirurgia de resignação sexual pode passar de dez anos. Disponível em: $<$ https://www.cartacapital.com.br/diversidade/Fila-para-cirurgia-deredesignacao-sexual-pode-passar-de-dez-anos>. Acesso em: 17 mai. 2018.

Conforme notícia publicada no sítio eletrônico do STF. Disponível em: $<$ http://www.stf.jus.br/portal/cms/verNoticiaDetalhe.asp?idConteudo $=3625$ 76>. Acesso em: 18 mai. 2018.

Conforme notícia publicada no sítio eletrônico do Superior Tribunal de Justiça. Disponível em:

$<$ http://www.stf.jus.br/portal/cms/verNoticiaDetalhe.asp?idConteudo $=3710$ 85>. Acesso em: 18 mai. 2018.

COSTA, Claudia de Lima. O feminismo e o pós-modernismo/pósestruturalismo: (in)determinações da identidade nas (entre)linhas do (con)texto In: PEDRO, Joana Maria; GROSSI, Miriam Pillar (Orgs.). Masculino, feminino, plural: gênero na interdisciplinariedade. Florianópolis: Editora Mulheres, 2000. p. 59 apud MARIANO. O Sujeito do Feminismo e o Pós-Estruturalismo In: Rev. Estud. Fem. v. 13, no. 3. Florianópolis: Sept./Dec. 2005.

Decreto 2724/02. Disponível em:

$<$ https://www.sssalud.gob.ar/pmo/res_201.php>. Acesso em: 15 mai. 2018.

Definição sobre identidade de gênero primeiramente expressa no documento dos princípios de Yogyakarta. Disponível em:

$<$ http://www.clam.org.br/uploads/conteudo/principios_de_yogyakarta.pdf $>$ Acesso em: 23 mai. 2018.

DIAS. Maria Berenice. Transexualidade e o Direito de Casar. Disponível em:

$<\mathrm{http}: / /$ www.mariaberenice.com.br/manager/arq $/\left(\operatorname{cod} 2 \_788\right) 1$ _transexuali dade_e_o_direito_de_casar.pdf.>. Acesso em: 16 mai. 2018. 
Disponível em: <http://justificando.cartacapital.com.br/2017/09/15/o-quepede-terceira-onda-feminista/>. Acesso em: 12 mai. 2018.

Disponível

em:

$<$ http://publicadireito.com.br/artigos/?cod=56dbbe315d23b256>. Acesso em: 18 mai. 2018.

Disponível em: <http://www.datasus.gov.br/cid10/V2008/cid10.htm> Acesso em: 19 mai. 2018.

Disponível em: $<$ https://www.correio24horas.com.br/noticia/nid/apenascinco-hospitais-fazem-cirurgia-transgenital-pelo-sus-no-brasil/>. Acesso em: 17 mai. 2018.

Disponível em:

$<$ http://operamundi.uol.com.br/conteudo/noticias/21754/argentina+aprova + lei + que + permite + mudanca + de + sexo + em + documentos + de + cidadaos + transg eneros.shtml $\geq$. Acesso em: 20 mai. 2018.

Disponível em:

$<$ http://www.publicadireito.com.br/artigos/?cod=4c9d1 fbce4890fc2>. Acesso em: 15 mai. 2018.

Disponível em: $\quad<$ http://www2.dbd.pucrio.br/pergamum/tesesabertas/1211273_2014_cap_2.pdf $>$. Acesso em: 11 mai. 2018.

Disponível em: $\quad<$ http://agenciabrasil.ebc.com.br/geral/noticia/201801/atualizacao-da-classificacao-de-doencas-tera-transtornos-por-jogoseletronicos>. Acesso em: 12 mai. 2018.

GONÇALVES, Camila de Jesus Mello. Transexualidade e direitos humanos: o reconhecimento da identidade de gênero entre os direitos da personalidade.Curitiba: Juruá, 2014.

GRANT, Carolina. Direito e gênero em trânsito: Quando corpos e gêneros em trânsito obrigam o Direito - uma análise crítica da ley de identidad de género argentina e do PL 5002/2013 a partir dos estudos queer. p. 24. Disponível em: $<$ http://www.publicadireito.com.br/artigos/?cod=f01287d4b412a2b1>. Acesso em: 15 mai. 2018. 
HEINZELAMANN, Fernanda Lyrio. Lei de Identidade de Gênero: Podem experiências sul-americanas colaborar com o Brasil? In: 13th Women's Worlds Congress \& Fazendo Gênero 11 e. ISSN 2179 -501X. Anais... Florianópolis, 2017, Disponível em:

$<$ http://www.en.wwc2017.eventos.dype.com.br/resources/anais/149858575 6_ARQUIVO_HEINZELMANN_FRACCAROLI_FG_2017_Lei_de_ident idade_de_genero.pdf> Acesso em: 23 mai. 2018.

Internacional de Educação Sexual: Feminismos, Identidades de Gêneros e Políticas Publicas. UEM. p. 5. Disponível em:

$<$ http://www.sies.uem.br/trabalhos/2015/588.pdf $>$. Acesso em: 15 mai. 2018 .

JESUS, Jaqueline Gomes de. Orientações sobre a população transgênero: conceitos e termos. Brasília: Autor, 2012.

JESUS, Jaqueline Gomes de. Orientações sobre identidade de gênero: conceitos e termos. $2^{a}$ ed. Brasília, 2012. p. 7-12. Disponível em:

$<$ https://issuu.com/jaquelinejesus/docs/orienta_es_sobre_identidade_de_g nero_conceitos_>. Acesso em: 15 mai. 2018.

ARGENTINA. Ley n. 17.132 de janeiro de 1967. Disponível em: $<$ http://servicios.infoleg.gob.ar/infolegInternet/anexos/1500019999/19429/norma.htm>. Acesso em: 20 mai. 2018.

LICÍNIO, José Vaughan Jennings Holanda. Uma crítica queer ao tratamento jurídico do casamento igualitário e da mudança de sexo no Brasil. Márcia Nina Bernardes (Orientadora). Rio de Janeiro, 2014. Monografia (Graduação em Direito) - Departamento de Direito, PUC-Rio, 2014.

MARIANO, Silvana Aparecida. O sujeito do feminismo e o pósestrutulismo In: Rev. Estud. Fem. v. 13, no. 3. Florianópolis: Sept./Dec. 2005 , p. 3. Disponível em: <http://dx.doi.org/10.1590/S0104026X2005000300002>. Acesso em: 28 mar. 2018.

MOLINA, Luana Pagano Peres. A Visibilidade dos/as transexuais da Argentina: A experiência da escola Mocha Celis e a criação da Lei de Identidade de Gênero In: IV Simpósio, Internacional de Educação Sexual: Feminismos, Identidades de Gêneros e Políticas Publicas. 2015, Buenos Aires. Anais... Buenos Aires, 2015. p. 5. Disponível em: 
$<$ http://www.sies.uem.br/trabalhos/2015/588.pdf $>$. Acesso em: 15 mai. 2018.

NETO, Clarindo Epaminondas de Sá. Identidade de Gênero: Um caminho entre a visibilidade e a invisibilidade In: Publica Direito. São Paulo, 2013.

Notícias sobre a publicação da CDI-11 e sobre a retirada do "transexualismo" do rol de doenças mentais. Disponível em:

$<$ https://www.revistaencontro.com.br/canal/atualidades/2018/01/omsreconhece-a-obsessao-por-games.html>. Acesso em: 12 mai. 2018.

PEREIRA, Júlia Mendes. O reconhecimento da identidade de gênero como processo emancipatório: percursos legais. Disponível em:

$<$ http://www.acomuna.net/index.php/contra-corrente/4625-o-

reconhecimento-da-identidade-de-genero-como-processo-emancipatoriopercursos-legais>. Acesso em: 15 mai. 2018.

Petição Inicial da ADI. p. 01. Disponível em:

$<$ http://www.mpf.mp.br/pgr/copy_of_pdfs/ADI\%204275.pdf/view>.

Acesso em: 18 mai. 2018.

Portaria n. 1.707/2008 do Ministério da Saúde. Disponível em: $<$ http://bvsms.saude.gov.br/bvs/saudelegis/gm/2008/prt1707_18_08_2008.h tml>. Acesso em: 16 mai. 2018.

Resolução n. 1482/1997 do Conselho Federal de Medicina. Disponível em: $<$ http://www.portalmedico.org.br/resolucoes/cfm/1997/1482_1997.htm>. Acesso em: 16 mai. 2018.

Resolução n. 1652/2002 do Conselho Federal de Medicina. Disponível em: $<$ http://www.portalmedico.org.br/resolucoes/cfm/2002/1652_2002.htm>. Acesso em: 16 mai. 2018.

Resolução n. 1955/2010 do Conselho Federal de Medicina. Disponível em: $<$ http://www.portalmedico.org.br/resolucoes/CFM/2010/1955_2010.htm>. Acesso em: 16 mai. 2018.

REsp 1008398/SP, Rel. Ministra NANCY ANDRIGHI, TERCEIRA TURMA, Julgamento em: 15.10.2009, DJe 18.11.09; e REsp 670422 RG, Rel. Ministro JOÃO OTÁVIO DE NORONHA, QUARTA TURMA, Julgamento em: 10.11.09, DJe 18.12.09. 
REsp 678.933/RS, Rel. Ministro CARLOS ALBERTO MENEZES DIREITO, TERCEIRA TURMA, Julgamento em: 22.03.07, DJ 21.05.07.

SARLET, Ingo Wolfgang. A eficácia dos direitos fundamentais. $2^{\mathrm{a}}$ ed. Porto Alegre: Livraria do Advogado, 2001.

SCOTT, Joan W. Gênero: uma categoria útil de análise histórica In: Educação e Realidade. Porto Alegre, v. 16, n. 2, 1990.

Segunda onda feminista desigualdades culturais-discriminação e políticas das mulheres. Disponível em:

$<$ http://justificando.cartacapital.com.br/2017/09/14/segunda-ondafeminista-desigualdades-culturais-discriminacao-e-politicas-das-mulheres/>. Acesso em: 11 mai. 2018.

SILVA, Bruna Camilo de Souza Lima e. Lei de Identidade de Gênero: Uma Análise Comparativa da Lei Argentina e o PL 5002/2013 do Brasil In: Libertas. Ouro Preto. ISSN 2319-0159 v. 2, nº 1, jan/ jun., 2016.

SILVA, Christiane Gonçalves da. Orientação sexual, identidades sexuais e identidade de gênero. Disponível em:

$<\mathrm{http}$ ://www.comfor.unifesp.br/wp-

content/docs/COMFOR/biblioteca_virtual/GDE/mod3/Semana3_Mod3_G

DE.pdf $>$. Acesso em: 02 jun. 2018.

STF, ADI 4277, Tribunal Pleno, Rel. Min. Ayres Britto, Julgamento em: 05/05/2011. Disponível em:

$<$ http://redir.stf.jus.br/paginadorpub/paginador.jsp?docTP $=\mathrm{AC} \&$ docID $=628$ 635>. Acesso em: 28 mai. 2017.

STF. ADI 4275. Voto Ministro Celso de Mello. Julgamento em: 01 mar. 2018. p. 10. Disponível em:

$<$ http://www.stf.jus.br/arquivo/cms/noticiaNoticiaStf/anexo/ADI4.275DFV otodoMin.CelsodeMello.pdf>. Acesso em: 21 mai. 2018.

URUGUAI. Ley n. 18.620: Derecho a la indentidad de género y al cambio de nombre y sexo en documentos identificatorios. Promulgada em outubro de 2009. Disponível em:

$<$ https://legislativo.parlamento.gub.uy/temporales/leytemp2085096.htm>. Acesso em: 15 mai. 2018. 
WYLLYS, Jean. Esclarecimentos sobre o PL 5002/2013 “João Nery”, no quetange ao direito à identidade de gênero de pessoas menores de 18 anos de idade. Disponível em: <http://jeanwyllys.com.br/wp/esclarecimentossobre-opl-50022013-joao-nery-no-que-tange-ao-direito-a-identidade-degenero-depessoas-menores-de-18-anos-de-idade>. Acesso em: 20 mai. 2018. 